\title{
Assessing phytoplankton realized niches using a French National Phytoplankton Monitoring Network
}

\author{
Hernandez Farinas Tania ${ }^{1,{ }^{*}}$, Bacher Cedric ${ }^{2}$, Soudant Dominique ${ }^{1}$, Belin Catherine ${ }^{1}$, Barille Laurent ${ }^{3}$ \\ ${ }^{1}$ IFREMER, Dyneco/VIGIES, Rue de I'lle d'Yeu, BP 21105, 44311 Nantes Cedex 03, France \\ 2 IFREMER, Dyneco/BENTHOS, Technopôle Brest Iroise, BP 70, 29280 Plouzané, France \\ ${ }^{3}$ Université de Nantes, Mer Molécules Santé EA 2160, Faculté des Sciences et des Techniques, 2, Rue \\ de la Houssinière, BP 92208, 44322 Nantes Cedex 03, France
}

*Corresponding author : Tania Hernandez Farinas, email address : tania.hernandez.farinas@ifremer.fr

\begin{abstract}
:
Relating environmental factors to species occurrence is a fundamental step in a better understanding of the community structure, the spatial and temporal dynamics of populations and how species may respond to environmental changes. In this paper, we used phytoplankton occurrence data, from a French national phytoplankton monitoring network, and environmental variables with the aim of characterizing the realized ecological niches of phytoplankton groups. We selected 35 phytoplankton taxa representing the most important taxa in terms of occurrence frequency and abundance along the French coast of the eastern English Channel, the Southern Bight of the North Sea and the Atlantic Ocean. We show that environmental variables such as nutrient concentration, water temperature, irradiance and turbidity can be considered key factors controlling phytoplankton dynamics and influencing the community structure. By using a statistical framework based on an ordination technique the community structure was analyzed and interpreted in terms of niche overlap, marginality and tolerance. The most marginal taxon was Dactyliosolen and the most tolerant was Skeletonema. Nonmarginal taxonomic units could be generalist and specialist, while marginal taxa were rather specialist. Specialist and marginal taxa globally showed lower values of overlap. Keywords
\end{abstract}

Keywords : phytoplankton, environment, niche position, tolerance, kernel density, outlying mean index 


\section{Introduction}

Understanding relationships between species and the environment have always been a central goal and a challenge for many studies in ecology (Guisan and Thuiller, 2005 and Araújo and Guisan, 2006). It is expected that environmental modifications resulting from human activities will impact the community structure by modulating species interactions and functional traits and therefore how the ecosystem functions. Thus, understanding the influence of environmental parameters on the abundance, the distribution of species and the community structure may contribute to a better understanding of species responses to future environmental changes.

In marine ecosystems, phytoplankton constitutes the base of food web, and its specific composition determines the pathways and efficiencies of the energy transfer to higher trophic levels (Cloern and Dufford, 2005). In addition, several species of phytoplankton have been linked to toxic events affecting marine wildlife, human health and activities such as fisheries and aquaculture (Lefebvre et al., 2002 and Sellner et al., 2003). Phytoplankton is sensitive to environmental changes and modifications in the community composition, the species abundances and the phenology may impact the functioning of marine ecosystems (Edwards and Richardson, 2004 and Hays et al., 2005). Eutrophication processes may enhance primary production and lead to hypoxic zones in coastal ecosystems (Diaz and Rosenberg, 2008). Global warming is expected to impact the geographical distribution of phytoplankton species and led to modifications on diversity (Thomas et al., 2012). 
An interesting approach to assess the environmental influence on phytoplankton species and community structure is to define the ecological niche of species. Hutchinson (1957) defined the niche as the space of environmental conditions in which a species is able to persist. Thereby, all the environmental factors essential to the existence of a species may be considered as the axes of a multidimensional coordinate system. The space the species is occupying within this coordinate system represents a hypervolume, which is also known as its fundamental niche. The fundamental niche described the potential space occupied by a species when biotic interactions are not taken into account. The term 'realized niche' relates to the portion of the fundamental niche in which a species has a positive growth constrained by the effect of competition or other biotic interactions such as predation (Pearman et al., 2008). Thus, the observed patterns of species distribution would reflect their realized niche but not necessarily all the potential space that a species could occupy. Concerning phytoplankton, laboratory work under controlled conditions provides information on the fundamental niche of phytoplankton species (Litchman and Klausmeier, 2008; Litchman et al., 2007) while in the field, the realized niche results from environmental factors varying continuously and interacting between each other. Thus, the realized niche may differ significantly from that constructed from lab-based experiments (Grüner et al., 2011). Different measures of niche characteristics have been suggested in order to describe the variability of species responses to abiotic and biotic environmental conditions (Dolédec et al., 2000). Niche position and niche breadth have been applied, for example, to separate niches of invasive plant species based on climate, landscape and human-pressure factors (Thuiller et al., 2012). The multidimensional space shared by two or more species called niche overlap (Geange et al., 2011; Mouillot et al., 2005) has been widely used to investigate resource partitioning (Schoener, 1968) and, more recently, to compare the space occupied by native and non-native populations of invasive species (Broennimann et al., 2007). A range of 
methods has already been used to determine species niches and to assess niche differences. These approaches typically involve ordination (Broennimann et al., 2007; Dolédec et al., 2000; Grüner et al., 2011) and species distribution modeling techniques (SDM) (Irwin et al., 2012). Ordination techniques, in particular, can be used to summarize multivariate environmental data and relate species occurrences to the environment by constructing synthetic axes estimated from the environmental data (Broennimann et al., 2012). Some of these have a good performance in describing either unimodal or linear response curves between species and their environment (Dolédec et al., 2000). Furthermore, Broennimann et al. (2012) compared different statistical methods to quantify the overlap between any taxonomical, geographical or temporal group of organism occurrences and concluded that ordination techniques seem to be more suitable than SDM techniques to investigate niche overlap. While several approaches have been used to estimate the realized niche of phytoplankton species from environmental data, all these studies addressed the influence of key factors such as temperature, salinity, irradiance and macronutrients on the estimated niches of phytoplankton (Gebühr et al., 2009; Grüner et al., 2011; Irwin et al., 2012; Litchman et al., 2012).

Different types of data can be used for niche analyses (Geange et al., 2011; Irwin et al., 2012; Mouillot et al., 2005). For phytoplankton species, niche characteristics have already been studied using abundance-oriented methods (Gebühr et al., 2009; Heino and Soininen, 2006) among others. Furthermore, multiscale approaches are regarded as an important feature in studies of niche dynamics (Pearman et al., 2008). In this context, long-term phytoplankton monitoring networks provide a large amount of information in terms of community composition, abundance and conditions in which microphytoplankton species occur, covering both spatial and temporal scales. To our knowledge, only two well-known datasets, i.e. Helgoland Roads and Continuous Plankton Recorder monitoring surveys, have been analyzed 
very recently with respect to niche estimation of marine phytoplankton (Gebühr et al., 2009; Grüner et al., 2011; Irwin et al., 2012). The French National Phytoplankton and Phycotoxin Monitoring Network (REPHY) which is implemented and managed by the French Institute for the Exploitation of the Sea (IFREMER), studies: i) the spatial and temporal variability of phytoplankton communities along the French coast, and ii) the potential phycotoxinproducing species and their relationships with toxic shellfish outbreaks. Since 1987, this network has collected information on phytoplankton communities and currently provides a large database covering numerous sites with different hydrological characteristics.

The present study analyzed the realized niche of some phytoplankton groups based on the REPHY using an ordination method. We adopt a statistical framework to characterize the ecological niche of phytoplankton units and assess the main environmental factors shaping the community structure. This provides information about niche position and breadth and enables further assessment of the relationships between taxa through a niche overlap metric. Here we discuss the potential role of the different niche parameters in explaining present and future variations in phytoplankton communities.

2. Materials and Methods

2.1. Phytoplankton and environmental datasets

Since 1987, the REPHY has been acquiring information on phytoplankton communities along the French coast. Phytoplankton samples were acquired from fortnightly to a monthly frequency and together with measurements of water temperature $\left({ }^{\circ} \mathrm{C}\right)$, salinity (measured using the Practical Salinity Scale), turbidity (NTU) and inorganic nutrient concentrations (dissolved inorganic nitrogen, silicates and phosphates, $\mu \mathrm{mol} \mathrm{L}{ }^{-1}$ ). However, as measurements of inorganic nutrient concentrations were initiated between 1996 and 1999 for Atlantic coast sites, this study covers the data collected during the period 1999-2012. For this period, the percentages of missing values per variable are: temperature (1.6\%), salinity 
(1.2\%), turbidity $(2.2 \%)$, dissolved inorganic nitrogen $(11.2 \%)$, silicates $(7.7 \%)$ and

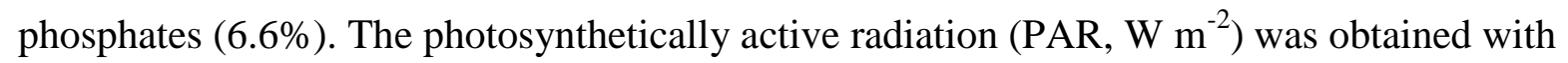
the ARPEGE model (Météo France) and the daily PAR was cumulated over five days before the phytoplankton sampling date.

The analysis was performed with 35 taxonomic units, which represent the most important taxa in terms of occurrence frequency and abundance (Table 1). Each taxonomic unit was defined as a group of species or genera. Such grouping aims to overcome difficulties of identification between some species or genera using optical microscopy. For example, during the identification process, some species might be aggregated into taxonomic groups (e.g. Protoperidinium - Peridinium group, PRP) to avoid identification errors when the differentiation between species and genus becomes difficult with optical microscopy. Some of these groups correspond to the taxonomic units extracted from the REPHY database. In addition, variations in taxonomic identification may arise due to changes in either taxonomists or training. Thus, grouping species or genera into taxonomic units was also necessary to guarantee the taxonomic homogeneity of the data over time and between different sampling sites. For further details on the sampling and processing of phytoplankton and environmental variables, see Aminot and Kérouel (2004, 2007), Belin and Neaud-Masson (2012), Grossel (2006), Hernández-Fariñas et al. (2014).

\subsection{Study area}

The study includes three geographical zones along the French coast of the eastern English Channel, the Southern Bight of the North Sea and the Atlantic Ocean (Fig. 1). Two sampling sites are located in the eastern English Channel ('Somme' and 'Boulogne') and one in the Southern Bight of the North Sea ("Dunkerque") (Fig. 1A). These areas are characterized by a large tidal range (between 3 and $9 \mathrm{~m}$ ) and are under the influence of freshwater inputs from the Seine, Somme and other rivers (Table 2, Lefebvre et al., 2011). 
During the spring period, this zone is also prone to recurrent proliferations of the foaming and noxious prymnesiophyte Phaeocystis globosa. In these areas, microphytoplankton communities are mainly dominated by diatoms and by $P$. globosa from March to May (Hernández-Fariñas et al., 2014).

Along the French coast at the Atlantic Ocean, there were three sampling stations ('Men er Roue', 'Ouest Loscolo' and 'Teychan', Fig. 1B, C, Table 2). The station 'Men er Roue is located in the Quiberon Bay, a zone protected from the open sea by the Quiberon peninsula and Houat Island. The sampling site of 'Ouest Loscolo', in Vilaine Bay, is under the direct influence of the Vilaine River (Table 2). The tidal range varies from 2.5 to $5 \mathrm{~m}$ (Vested et al., 2013). In this zone, freshwater influence is also provided by the Loire river (mean annual flow $931 \mathrm{~m}^{3} \mathrm{~s}^{-1}$ ) (David et al., 2012). Diatoms belonging to the genera Leptocylindrus, Skeletonema and Chaetoceros dominate the microphytoplankton community (Ifremer, Laboratoire Environnement Ressources Morbihan Pays de Loire, 2013). The sampling station of 'Teychan' is located in Arcachon Bay, a semi-enclosed embayment of $174 \mathrm{~km}^{2}$ connected to the Atlantic Ocean by two narrow channels (Fig. 1C) (Glé et al., 2008). The inner part of the bay is characterized by large intertidal areas through which tidal channels pass. The tide ranges between 0.9 and $4.9 \mathrm{~m}$, favoring water exchange with the oceanic waters (Glé et al., 2008). Although many small streams run into the bay, the principal freshwater input comes from the Leyre river (Table 2). At this location, the microphytoplankton community is often dominated by the diatom Asterionellopsis glacialis (Ifremer, Laboratoire Environnement Ressources d'Arcachon, 2013).

The study areas have a temperate climate under the influence of Atlantic Ocean waters and experience mild winters and summers. The variability of temperature $\left(8.2-19.6{ }^{\circ} \mathrm{C}\right)$, salinity (30.6 - 34.6), turbidity $\left(1.1\right.$ - 9 NTU), dissolved inorganic nitrogen $\left(1.1-40.4 \mu \mathrm{mol} \mathrm{L}^{-1}\right)$, silicates $\left(0.6-26.1 \mu \mathrm{mol} \mathrm{L}{ }^{-1}\right)$ and phosphates $\left(0.07-0.8 \mu \mathrm{mol} \mathrm{L}^{-1}\right)$ reflects the range of 
environmental conditions where phytoplankton communities were sampled (Table 3 and Fig.

S1).

2.3. Estimating the realized niche of phytoplankton taxonomic units

2.3.1. Niche properties of taxonomic units

The Outlying Mean Index analysis (OMI) was used to characterize the niche position and breadth of each taxonomic unit (Dolédec et al., 2000). For analytical purposes, the data were arranged in two data tables, a site-date taxonomic unit abundance table and a site-date environment table. Site-date samples were arranged as rows, phytoplankton units and environmental factors as columns. The abundance of taxonomic units was $\log 10(\mathrm{x}+1)-$ transformed in order to reduce the effect of dominant taxa. All analyses and graphical representations were performed with $\mathrm{R}$ software (R Core Team, 2013). The OMI analysis is implemented by the function 'niche' in the ade4 package in R (Dray and Dufour, 2007). This function takes as inputs a principal component analysis (PCA) performed on the environmental datasets, together with the table containing the abundance of taxonomic units. The probabilistic PCA (ppca in pcaMethods, Stacklies et al., 2007) was used for missing data estimation. This procedure embeds an expectation-maximization algorithm for estimating the maximum likelihood values of missing information (see for further details Roweis, 1998). This result was then used to compute the OMI.

The OMI analysis, developed by Dolédec et al. (2000), is an ordination technique that characterizes the niche of a taxonomic entity while looking for the most influencing variables that better separate the ecological niche of a set of taxonomic units. Another advantage of this method is its performance describing either unimodal or linear response curves between taxonomic units and their environment (Dolédec et al., 2000).The OMI method measures the niche position, the location of the realized niche in an $n$-dimensional space by the parameter marginality of species distribution. The OMI index (or taxonomic unit marginality) is defined 
as the distance between the mean habitat conditions used by the taxonomic unit and the mean habitat conditions over the entire studied area (origin of the niche hyperspace). Species with high values have marginal niches (occur in less common habitats in the studied region), and those with low values have non-marginal niches (occur in typical habitats in the region). The OMI method measures also the niche breadth by the parameter of species tolerance. The tolerance is associated to the variability of the environment used by the taxonomic unit. High tolerance values are associated with taxa occurring in a wide range of environmental conditions (generalist taxa) while low values of tolerance imply that the taxa are distributed across a limited range of environmental conditions (specialist taxa). A residual tolerance is also provided by the analysis, representing the part of variance that is not taken into account, which therefore helps to determine if the environmental variables are suitable for defining the niche of an entity (Dolédec et al., 2000).

The environmental variables included in the analysis were temperature, salinity, turbidity, photosynthetically active radiation, concentrations of total dissolved inorganic nitrogen, silicate and phosphate. Two additional variables were added in order to include biotic interactions in the phytoplankton community. These variables were the number of taxonomic units observed (as a measure of diversity richness) at each sample and the Berger-Parker dominance index. The latter indicates the ratio between the most abundant taxonomic unit and the total abundance in the community sample. Niche parameters were computed to compare the variability of taxonomic unit responses to environmental conditions and their influence on the niche separation between taxa. A permutation test (1000 permutations) was performed to determine whether the marginality of a taxonomic unit was different from that expected by chance. Rejection of the null hypothesis indicates that the taxonomic unit is not independent of its environment (Dolédec et al., 2000). 


\subsubsection{Niche overlap}

Broennimann et al. (2012) procedure was adapted to quantify the niche overlap between taxonomic units. A kernel density estimation weighted by abundance was applied ( $k s$ package for R; Duong, 2007) to determine the smoothed occurrence density for each taxonomic unit in an $r \times r$ gridded environmental space defined by the first and second axis of the OMI analysis (the $r$ value was set at 100, Fig. 2). The kernel procedure makes the estimation of the niche overlap independent of the $r$ value (Broennimann et al., 2012). This method has already been used to study the distribution of quantitative functional traits and to model species distributions (Hengl et al., 2009; Mouillot et al., 2005). Minimum/maximum values for the $r \times r$ grid were defined by the bounded coordinates of the OMI axes. In this analysis, the first two axes of the OMI were used. We are aware that more than two axes can be considered for niche analysis, but increasing dimensions can be challenging for the subsequent interpretation and representation of results. However, this procedure can also be performed with more than two dimensions.

To compare the realized niche between two taxonomic units, an overlap measure ( $D$ metric) (Schoener, 1970) was calculated:

$$
D_{1,2}=1-\frac{1}{2} \sum_{i j}\left|p_{1 i j}-p_{2 i j}\right|
$$

where $p_{1 i j}$ and $p_{2 i j}$ correspond to the normalized kernel density estimates for taxonomic units 1 and 2 , at each $i j$ cell of the grid previously defined. The $D$ value ranges from 0 (no overlap) to 1 (complete overlap). This metric was used because of its simplicity and widespread (Warren et al., 2008). $D$ was calculated for each pair of taxa, i.e. a total of 595 combinations. As $D$ may represent a measure of association between a pair of taxa, $(1-D)$ may be considered a distance measure for each pair of taxonomic units (Geange et al., 2011). These results were used to build an $n \times n$ matrix, where $n$ corresponds to the number of taxonomic units referenced in this study. A non-metric multidimensional scaling (nMDS) was used to 
graphically represent in two dimensions further relationships between taxa. This analysis was performed in $\mathrm{R}$ with the vegan package (Oksanen et al., 2014).

Niche similarity was tested between all the taxonomic units (Broennimann et al., 2012;

Warren et al., 2008) by applying the test described in Broennimann et al. (2012). The similarity test assesses whether the environmental space occupied by a taxonomic unit $(\mathrm{X})$ is more similar to the one occupied by another taxon (Y) than expected by chance. For this, the observed niche overlap between $\mathrm{X}$ and $\mathrm{Y}$ was compared to the overlap obtained between the estimated niche of $\mathrm{X}$ and a randomly created niche. To create random niches, the center of the niche of $\mathrm{Y}$ was shifted randomly within the boundaries of the available environment. Then the simulated overlap was calculated and the procedure was repeated 1000 times to construct the simulated distribution of $D$. If the observed value of $D$ is greater than $95 \%$ of the simulated values of $D$, the niche of $\mathrm{X}$ is more similar to the niche of $\mathrm{Y}$ than expected by chance. This test was performed on both directions. First, the niche of $\mathrm{X}$ was compared with the niche randomly shifted from Y. Secondly, the test was repeated in the opposite direction, between Y and the niche randomly shifted from X. X and Y were considered to have similar niches when the observed $D$ overlap was greater than $95 \%$ of the simulated values for both tests.

Finally, regression analyses were performed to examine the relationship between niche parameters and between these parameters and the occurrence frequency, i.e. the number of samples where a taxonomic unit was observed. These analyses were performed with the logittransformed occurrence frequency variable: $\log (y /[1-y])$ (Warton and Hui, 2011). Following the variable transformation, a linear regression was performed. The Cook distance was used to estimate the influence of data points. Points with a large distance of Cook were excluded from the linear regression. This was the case of the taxonomic units DAC and CER (regression between marginality and occurrence frequency), SKE (regression between tolerance and occurrence frequency) and PHA (regression between niche overlap and 
marginality). The occurrence frequency was graphically represented in its original scale. In addition, the Spearman correlation was calculated between these parameters.

3. Results

3.1. Marginality and tolerance of taxonomic units

The most important environmental variables separating the niche of taxonomic units were richness, light, temperature and nutrient concentration (Fig. 3). The first axis, representing $68.1 \%$ of the explained variability, captured the seasonal patterns of environmental variables: low temperature and light, well mixed conditions and high nutrient concentrations during the winter and nutrient decrease over the spring and summer, when the light levels, temperature and richness reach their maximum (Fig. 3A). The distribution and space occupied by Leptocylindrus (LEP) and Skeletonema (SKE), two dominant genera in the microphytoplankton community, are shown for illustrative purposes (Fig. 3B, C). Both genera appear frequently in the phytoplankton community along the French coast, but in different environmental conditions. Therefore, some differences can be observed concerning the extent of the ellipsoids and their relative position in the environmental space. Leptocylindrus exhibits a niche characterized by warmer temperatures and high light conditions while Skeletonema mainly occupies a niche with low light, high nutrient concentrations and cool environmental conditions. However, Skeletonema has a high tolerance, related to its occurrence under a wider range of environmental conditions (Fig. 3C, D and Table 4). The position of all the taxonomic units on the first axis of the OMI analysis and their respective tolerance are also shown (Fig. 3D, representation on the first two axes in Fig. S2). These niche parameters can be related to different environmental conditions. Along the environmental gradients, there were several taxonomic units with a position rather close to the origin of the niche hyperspace (low marginality, Table 4). These taxonomic units include, for example, the group of Nitzschia-Hantzschia (NIT) and Pleurosigma-Gyrosigma (PLE). Other 
taxa such as Dactyliosolen (DAC), Cerataulina (CER) and Phaeocystis (PHA) have higher values of marginality but a lower tolerance (Table 4). Some taxonomic units, for example Dictyocha (DIC), Heterocapsa (HET), and the group of Asterionella, Asterionellopsis and Asteroplanus (AST), have a high residual tolerance to the environmental variables defined in this analysis (Table 4). The permutation test showed that the marginality of all taxonomic units was different from that expected by chance $(P<0.01)$.

\subsection{Niche overlap}

The nMDS reveals associations of taxonomic units based on the measures of overlap (Fig. 4). Diatoms were distributed along both axes of the nMDS, while almost all the dinoflagellates were found having negative coordinates on the first axis. Taxonomic units which are distant from the other have lower overlap values and vice versa. The lowest value was observed between Ditylum (DIT) and Dactyliosolen $($ DAC) $($ overlap $=0.49)$, while a similar realized niche (overlap between 0.95 and 0.96 ) was observed between the taxonomic units Guinardia (GUI), Pseudo-nitzschia (PSE), and Rhizosolenia (RHI). A high overlap was observed between the diatom group Eucampia-Climacodium (EUC) and the dinoflagellate Katodinium (KAT) while these two taxa showed a relatively low overlap with other taxonomic units (Fig. 4, Table S1). Taxa pairs involving Phaeocystis (PHA) presented the lowest overlap values. A similar niche between taxonomic units was observed on 33\% of cases (Fig. 4). For example, Biddulphia (BID) showed a similar niche with Paralia sulcata (PARs) and Odontella (ODO) and dissimilar with taxa such as Dactyliosolen (DAC) and Alexandrium (ALE).

\subsection{Relation between niche parameters}

With increasing marginality the tolerance decreased, and thus, all taxonomic units with high marginality have low tolerance (Fig. 5A). For example, the most marginal taxonomic unit, Dactyliosolen (DAC), had a rather low tolerance, while Skeletonema (SKE) was the most tolerant unit and showed a low marginality. However, taxonomic units with low 
marginality could be both tolerant and non-tolerant. Non-marginal units with a low tolerance were mainly represented by diatoms, for example, the group Asterionella, Asterionellopsis and Asteroplanus (AST) and Thalassionema-Thalassiothrix-Lioloma (THL).

The occurrence frequency of taxonomic units was negatively related to the marginality $(\mathrm{p}<$ $10^{-4}$, Spearman correlation $\left.=-0.71\right)$ and positively to the tolerance $(\mathrm{p}<0.01$, Spearman correlation $=-0.53)($ Fig. $5 \mathrm{~B}, \mathrm{C})$. Thus, non-marginal taxonomic units were observed more frequently than those with a high marginality. Typically tolerant units occurred with a high frequency. However, there was a wide variation between the tolerance and the occurrence frequency. Taxonomic units with a similar tolerance may therefore present high variations in the frequency of occurrence. For example, the non-marginal and non-tolerant group formed by the diatoms Thalassionema-Thalassiothrix-Lioloma (THL) had a similar tolerance than the marginal diatoms Eucampia-Climacodium (EUC) while the occurrence frequency for these taxonomic units was 51.2 and $17.3 \%$ respectively.

Globally, non-marginal taxa presented the highest overlap and the lowest variability on this measure $(\mathrm{p}<0.001$, Spearman correlation $=-0.66$, Fig. 6A). Diatoms such as NitzschiaHantzschia (NIT), Chaetoceros (CHA), Thalassionema-Thalassiothrix-Lioloma (THL) and Asterionella-Asterionellopsis-Asteroplanus (AST) globally had a higher overlap with other taxonomic units $(D=0.84)$ while Dactyliosolen (DAC) and Phaeocystis (PHA) showed a lower overlap ( 0.72 and 0.68 respectively). No consistent relationship was observed between measures of overlap and tolerance (Fig. 6B). Low and high-tolerant taxonomic units may have a similar value of overlap, such as for example the diatoms group AsterionellaAsterionellopsis-Asteroplanus (AST) and the dinoflagellate group ProtoperidiniumPeridinium (PRP).

4. Discussion

4.1. Main environmental factors shaping the community structure 
When assessing the realized niche of phytoplankton units, an important question that arises is the choice of environmental variables to include in the analysis. In this study, light, temperature, richness and nutrient concentrations were the principal factors controlling phytoplankton dynamics and influencing the community structure. This is in accordance with laboratory experiments on the dependence of phytoplankton growth rate on the same factors (Eppley, 1972; Kiefer and Cullen, 1991; Litchman et al., 2003). Among the environmental variables, salinity plays a major role in defining the environmental gradient between estuaries and coastal systems. In the OMI analysis, this variable was not found to be an important factor for niche separation between taxa, showing that the taxa taken into account in this analysis were mainly formed by marine species occurring in near-coast systems. In addition, in our study, salinity varied mainly between 30.6 and 34.6. Given this narrow range, salinity seems to have little effect in terms of niche separation.

The OMI analysis provides a measure to determine if the environmental variables are suitable for determining the niche of an entity. Taxa such as the silicoflagellate Dictyocha (DIC), the dinoflagellate Heterocapsa (HET), and the diatom group of Asterionella, Asterionellopsis and Asteroplanus (AST) exhibit a high residual tolerance to environmental conditions (Table 4). Heino and Soininen (2006) also found a high residual tolerance (between 14.5 and 93.9) of numerous phytoplankton species, calculated by an OMI analysis. These results raise the question of how well the available environmental variables explain the niche. In our analysis, between 13.2 and $44.7 \%$ of the inertia was explained by the environmental factors for each taxonomic unit. Despite these values, the results of the permutation test (rejection of the null hypothesis for all taxa) suggest a significant influence of the environmental variables on all taxa. These results indicate that although the environmental variables used in this study significantly influence all the taxonomic units, other factors that were not taken into account, 
such as micronutrient concentrations, grazing or parasite pressure may strongly influence some taxa (Litchman and Klausmeier, 2008).

In particular, biotic interactions are likely to impact the spatial and temporal distribution of phytoplankton species. Within biotic factors included in the analysis, the richness parameter had an important role defining the assemblage structure, providing some insight about the degree of co-occurrence or nestedness between phytoplankton taxonomic units. The number of taxonomic units co-occurring reflects specific interactions (whether positive or negative) inside the community and shaping its structure. Furthermore, top-down processes, such as predation, control the dynamic of algal blooms and phytoplankton is also vulnerable to parasites and pathogens such as fungi, bacteria and viruses (Litchman and Klausmeier, 2008). No data of grazing pressure were formally included in this analysis, although some dinoflagellates also feed by engulfing prey cells (e.g. species within the group of Gymnodinium-Gyrodinium, Noctiluca scintillans). Thus, this kind of analyses may give some evidence on the little known prey-predator relationships within (phyto)plankton. However, the degree to which biotic interactions act as a selective pressure defining the realized niche of species is difficult to estimate, since little information is available on these interactions and specially about the vulnerability and resistance of taxonomic units facing these pressures. Species Distribution Models rely upon niche theory to predict phytoplankton response across an array of environmental variables, most often nutrients, light, temperature and salinity (Irwin et al., 2012). Nevertheless, species-interactions are often neglected (Thomas et al., 2012). This lack of information may lead to under- or over-estimate the response of phytoplankton units to environmental variations, especially in the context of future impacts on marine ecosystems. This highlights the importance of monitoring networks to cover the major ecosystem components (Koslow and Couture, 2013).

4.2. Analysis of niche properties 
Differences on niche parameters between taxonomic units reflect their specific phylogenetic and life cycle attributes which determines the relationship with the environment and the interaction with other taxa. Our results show a clear variation in the degree of tolerance within these taxonomic units. Thus, non-marginal taxa were not always generalist. In fact, some nonmarginal taxa were widely distributed (e.g. Gymnodinium-Gyrodinium, Skeletonema) while other taxa were rather specialist and then restricted to mean environmental conditions found within these regions (e.g. Dictyocha). Alternatively, marginal units were always associated with lower tolerances, and as expected, a lower frequency of occurrence (e.g. Dactyliosolen). When studying the regional occupancy of stream diatoms, Heino and Soininen (2006) found that the marginality and the tolerance were not correlated. However, these authors pointed out that generalist species may occur in atypical environmental conditions and may also be able to occur more widely, a result not observed in our study.

Skeletonema (SKE) had the highest tolerance and can be considered to be generalist (Fig. 3D, Table 4). This chain-forming diatom which appears mainly during the winter-spring period has been previously found to have a moderate niche breadth (Ignatiades, 1994). Its presence across the sites, and its occasional appearance during the summer period, has largely contributed to its niche enlargement. The relatively varied environmental conditions in which this diatom can be observed are considered an asset for the intensive rearing of the Pacific oyster Crassostrea gigas (Méléder et al., 2001). The most specialized taxon in the dataset was the diatom Dactyliosolen as it showed a narrow niche breadth and the highest value of marginality.

High overlap values were not only observed between generalist taxa but also among some specialists (Fig. 6). More specialist but also non-marginal taxa such as the group Thalassionema-Thalassiothrix-Lioloma (THL) have globally high overlap values with other taxonomic units. This result highlights nested patterns between non-marginal taxonomic units, 
whether they were specialist or not. Conversely, marginal units showed low overlap values, and more widely, a high variability of this measure (e.g. Dactyliosolen). Even if the overlap measure globally varies between 0.5 and 0.9 , the high overlap also reflected co-occurrence patterns. The 'inconsistency' between the high diversity of species observed in plankton and the principle of competitive exclusion was stated by Hutchinson (1961) as the 'paradox of plankton'. Several mechanisms were advanced as solutions to this paradox and anticipated by Hutchinson (1961), including environmental variability at all scales and biological interactions which magnify (rather than damping) the effects of environmental variability on communities (Scheffer et al., 2003). These mechanisms lead to non-equilibrium states in the community (Cloern and Dufford, 2005). Despite the high overlap values observed, the test of similarity was not significant in $67 \%$ of the cases, indicating that realized niches were often not similar and highlighting the role of the environment in shaping communities and providing habitats for niche differentiation.

In addition, overlap measures depend on available variables. For example, two taxonomic units may occupy a similar space (high overlap) but adding an additional variable as the ability of vertical migration (as observed in dinoflagellates) in the water column may relax the co-existence and decrease the niche overlap. In this context, the OMI analysis takes advantage of its possibility to extract the most important variables structuring phytoplankton assemblages. When using other ordination techniques such as Principal Component Analysis as a way to reduce the number of dimensions, adding irrelevant factors to the analysis may lead to a misinterpretation of the results because unimportant information is reflected in the principal components (Grüner et al., 2011).

\subsection{Potential responses to environmental changes}

It is also valuable to relate niche properties with the sensitivity of taxonomic units under multiple stressors such as global climate change, invasive species or nutrient enrichment 
process. It may be expected that marginal species will be more sensitive to environmental changes or that generalist taxa could be favored. In all the cases, marginality should always be analyzed with respect to environmental ranges and the direction of changes. For example, taxonomic units observed within atypical high temperatures would have a high marginality, but it could be favored under predictions of increases in water temperatures. Moreover, the niche positions within environmental gradient are informative about their potential responses to changes. In the Bay of Biscay (North East Atlantic) a warming rate of $0.2^{\circ} \mathrm{C} / \mathrm{decade}$ was observed between 1965 and 2004, with cooling periods (until early 1970's) and more stronger increase in the temperature during the last 20 years $\left(\sim 0.3^{\circ} \mathrm{C} /\right.$ decade from 1986$)$ (Michel et al., 2009). In a context of warmer waters, taxonomic units occurring under warm conditions (e.g. Ceratium, Alexandrium, Dactyliosolen in our study) would benefit and even expand their temporal and spatial distribution, while cold-likely units may decrease or rather be observed northward. For instance, members of the genus Ceratium (CEI) only recorded in southern England before 1970 have expanded their range into the west of Scotland and the north of the North Sea (see Hays et al., 2005). In our analysis Ceratium had a moderate marginality and tolerance (Fig. 5A), and niche position (Fig. 3D) showed that this taxon was favored by warmer temperature compared to the temperature range in the studied area. Similarly, the (re)establishment of ten species in the North Sea, considered as 'thermophilic' (species found in southern and warmer waters, e.g. Alexandrium minutum, Gymnodinium catenatum) coincides with a period of slightly increased sea surface temperature anomalies in the northern ocean (around $0.2^{\circ} \mathrm{C}$ between 1980 and 1991) (Houghton et al., 1992; Nehring, 1998).

One also might expect that generalist taxonomic units would be less prone to environmental changes than the specialist ones, as they frequently appear within a wide range of environmental conditions. Some studies supported this notion, and highlighted that specialist species with restricted tolerances are predicted to lose a high proportion of their habitat while 
generalist species only expand within the limits of the available habitat (Thuiller et al., 2005, Pradervand et al., 2014). Moreover, the success of invasive organisms has been related to their plasticity and their capacity to use a wide range of habitats (Schmid, 1984). The successful invasion of the dinoflagellate Prorocentrum minimum on the Baltic Sea was favored by their high tolerance to variations on temperature, salinity, low-light conditions and their capacity to use mixotrophy when nutrients were scarce (see Olenina et al., 2010). In this context, coupling the inter-annual environmental variability with the ecological niche theory (Helaouët et al., 2013) could allow to assess to which extent, generalist or specialist taxa will be affected by environmental changes.

\subsection{Links with life-strategies}

The organization of phytoplankton communities can be approached at the level of cell size and form, behavior (motile versus non-motile), or life forms (e.g. pelagic versus benthic taxa). Considering the variability in phytoplankton traits provides further explanations about the mechanisms behind diversity patterns and the structure of communities (Litchman et al., 2010). For example, the Mandala model (Margalef, 1978) and the CSR scheme (standing for competitors, stress-tolerant and ruderal, Reynolds, 2006) are attempts to define functional groups that highlight the adaptation of different life forms to specific habitats. According to Reynolds (2006), the $C$-strategists are small, fast growing species with a high surface/volume ratio and are expected to dominate under high stratification conditions and high nutrient concentrations. The $S$-species are large, with a low surface/volume ratio and are thought to dominate in oligotrophic waters, taking advantage of their ability to migrate or to use mixotrophy to obtain nutrients. The $R$-strategists have an elongated form and are found under high mixing conditions and high nutrients levels.

In our study, typical $R$-strategists, such as the chain-forming Skeletonema, ThalassiosiraPorosira and the group formed by Asterionella, Asterionellopsis and Asteroplanus, were able 
to exploit environments with a low light and high nutrient concentration (see Fig. 3D and S2).

The large and motile genus Ceratium was previously associated to the $S$-strategy, which combines the presence of structures like horns to reduce sinking rates and the ability to perform vertical migrations (Reynolds, 2006). This taxon had a moderate marginality and tolerance (Table 4), and was mainly observed during low nutrient concentrations and low turbidity (Fig. S2). Nevertheless, the niche position along the environmental conditions not always confirmed the $C S R$-strategies. Coscinodiscus was previously associated to the $S$ strategy (Alves-de-Souza et al., 2008), but this diatom was mainly associated with low light and high nutrient levels (see Fig. S2). In fact, some species of Coscinodiscus (e.g. C. wailesii) have been observed to form blooms that impact aquaculture activities by removing nutrients such as inorganic nitrogen during winter and spring (Manabe and Ishio, 1991; Nagai et al., 1995). There are probably more complex patterns regarding phytoplankton strategies, as some genera appear to have species with different strategies or intermediate characters of the CSRscheme (Smayda and Reynolds, 2002, Reynolds, 2006).

Another key to interpret our niche results was related to the life form of some diatoms. Genera such as Biddulphia (BID), Odontella (ODO) and Paralia sulcata (PARs) live mostly in a benthic environment but may also be observed in plankton. The NAV group identified in this study is mainly formed by benthic microalgae. Navicula spp. are recognized as epipelic diatoms, a major group of microalgae occupying sediments (Thornton et al., 2002; Underwood, 1994). The genera Fallacia, Petroneis and Lyrella are groups commonly found on sandy sediments (Round et al., 1990; Sabbe et al., 1999). The high overlap values observed between these taxa probably mean that they co-occur in the water column when strong winds, tidal mixing and waves facilitate resuspension of microphytobenthos into the phytoplankton (De Jonge and Van Beusekom, 1995). Furthermore, taxa such as Biddulphia, Odontella and Paralia sulcata are positively associated with turbidity (see both Fig. 3A and Fig. S2), a 
variable related to resuspension phenomena. Environmental variables such as surface sediment temperature, salinity, nutrient concentrations and sediment type have been considered factors that may affect the microphytobenthic biomass and species composition (Ribeiro et al., 2013; Thornton et al., 2002; Underwood et al., 1998). Hence, niche parameters of these taxa represented their distribution in the water column but they do not necessarily provide an accurate ecological niche description for microphytobenthos taxa within their sediment habitat.

\subsection{Influence of taxonomic resolution}

A necessary step in our data processing was to regroup different species within taxonomic units to guarantee homogenous datasets when comparing multiple sites across time. Those taxonomic units represent taxa at different levels, from species to a set of different genera. It may be expected that such a grouping would impact the realized niche estimates and, to some extent, it certainly does. Grouping several species in such taxonomic units may lead to a wider realized niche, given the large extent of the occupied space. This may be the result of the sum of different realized niches of species forming the taxonomic units. Nevertheless, species associated to a taxonomic unit are usually morphologically similar and similar realized niches may also be expected. In fact, the morphological characteristics of phytoplankton species have been related to physiological traits such as maximal growth rate, sinking rate and resource gathering (light and nutrients) (Kruk et al., 2010) and in turn, traits define to a large extent both fundamental and realized niches (Litchman et al., 2007). However, some studies show that morphologically similar species can occur at different periods of the year (Siano, 2007). On the other hand, different morphotypes of the diatom Pseudo-nitzschia galaxiae, i.e with different cell sizes, have different seasonal patterns (Cerino et al., 2005). The groups identified in our study, such as the genera Chaetoceros (CHA), Prorocentrum (PRO), the group of Gymnodinum-Gyrodinium (GYM) and 
Protoperidinium-Peridinium (PRP), are in fact a complex assemblage of different species having a variable life-history. This could explain the central position of these taxa on the nMDS and why these phytoplankton units have a high overlap measure when their realized niche is compared with other taxa, a non-marginal position and a moderate-to-high tolerance. As expected, the estimated niche of these taxa tends to be more similar to the niche of almost all taxonomic units than expected by chance (Fig. 4). However, in some cases several species within the same genera may share a similar environmental space. This was especially the case of the group Ceratium (CER) where Neoceratium furca and N. fusus occupy a similar space (results not shown). Furthermore, numbers of taxonomic units were mainly formed by one species (see Table 1). In these cases, the realized niche of the taxonomic units corresponds to the species one (e.g. Skeletonema costatum).

These results highlighted that, in some cases, species phylogenetically close may occupy, to some extent, a different environmental space reflecting possible differences in biological traits. A functional approach implying traits may be very informative and could also be considered when defining the niche of individual species (Litchman et al., 2012).

\section{Conclusions}

In this study, a statistical framework was adopted and tested to investigate the realized niche of phytoplankton taxa in relation to environmental conditions covering 14 years and 6 regions along the French Atlantic coast. Integrating the OMI analysis with the kernel density estimation provided: (i) quantitative information about the marginality and tolerance of taxonomic units, (ii) indications of how well the environmental variables explain the niches, and (iii) measures of the space shared between two niches on the basis of a set of environmental variables. Using these parameters, the realized niches of 35 phytoplankton taxonomic units have been characterized and further associations between them have been explained. The analysis showed that marginal taxonomic units were always the most 
specialized taxa. However, within specialist taxa, some taxonomic units were non-marginal while other taxa were marginal. Specialist and marginal taxa globally showed lower values of overlap. The niche approach has also been related to actual concerns about phytoplankton responses to multiple environmental stressors such as climate change or invasive species. In addition, the influence of the level of taxonomic classification available on niche estimates has been discussed.

The association between the OMI analysis and the kernel density estimation will be further exploited. Extracting high-density regions for each taxonomic unit allowed exploring the lower and upper limits of environmental conditions where they occurred (Figure 3B, C). Interesting ecological questions can be approached by comparing, with niche overlap, the environmental space occupied by a species through different geographical locations: are niche differences between sites a reflection of local adaptations, different strains of species or only reflect the heterogeneity of environmental conditions? Answering this question shall provide a better comprehension of evolutionary phytoplankton strategies in a context of future changes.

\section{Acknowledgements}

We thank Emmanuel Blondel, Raffaele Siano and Luis Lampert for their assistance and helpful discussions. We are also grateful to Romain Le Gendre for providing the photosynthetically active radiation (PAR) measurements. We also want to acknowledge the two anonymous reviewers for their valuable suggestions that greatly improved the manuscript. This study was carried out thanks to the long-term work of many people involved in the REPHY monitoring network and other supporting programs. This research is part of a PhD Thesis funded by the Fondation de France and the IFREMER. 
References

Alves-de-Souza, C., González, M. T., Iriarte, J. L., 2008. Functional groups in marine phytoplankton assemblages dominated by diatoms in fjords of southern Chile. Journal of Plankton Research 30 : 1233-1243.

Aminot, A., Kérouel, R., 2004. Hydrologie des écosystèmes marins. Paramètres et analyses. IFREMER, Paris, 336 pp.

Aminot, A., Kérouel, R., 2007. Dosage automatique des nutriments dans les eaux marines. Méthodes en flux continu. IFREMER, Paris, 188 pp.

Araújo, M.B., Guisan, A., 2006. Five (or so) challenges for species distribution modelling. Journal of Biogeography 33, 1677-1688. doi:10.1111/j.1365-2699.2006.01584.x

Belin, C., Neaud-Masson, N., 2012. Cahier de Procédures REPHY 2013. IFREMER, 81 pp.

Broennimann, O., Fitzpatrick, M.C., Pearman, P.B., Petitpierre, B., Pellissier, L., Yoccoz, N.G., Thuiller, W., Fortin, M.-J., Randin, C., Zimmermann, N.E., Graham, C.H., Guisan, A., 2012. Measuring ecological niche overlap from occurrence and spatial environmental data. Global Ecology and Biogeography 21, 481-497. doi:10.1111/j.1466-8238.2011.00698.x

Broennimann, O., Treier, U.A., Müller-Schärer, H., Thuiller, W., Peterson, A.T., Guisan, A., 2007. Evidence of climatic niche shift during biological invasion. Ecology Letters 10, 701-709. doi:10.1111/j.1461-0248.2007.01060.x

Cerino, F., Orsini, L., Sarno, D., Dell'Aversano, C., Tartaglione, L., Zingone, A., 2005. The alternation of different morphotypes in the seasonal cycle of the toxic diatom Pseudonitzschia galaxiae. Harmful Algae 4, 33-48. doi:10.1016/j.hal.2003.10.005

Cloern, J.E., Dufford, R., 2005. Phytoplankton community ecology: principles applied in San Francisco Bay. Marine Ecology Progress Series 285, 11-28. doi:10.3354/meps285011 
David, V., Ryckaert, M., Karpytchev, M., Bacher, C., Arnaudeau, V., Vidal, N., Maurer, D., Niquil, N., 2012. Spatial and long-term changes in the functional and structural phytoplankton communities along the French Atlantic coast. Estuarine, Coastal and Shelf Science 108, 37-51. doi: 10.1016/j.ecss.2012.02.017

De Jonge, V.N., Van Beusekom, J.E.E., 1995. Wind- and tide-induced resuspension of sediment and microphytobenthos from tidal flats in the Ems estuary. Limnology and oceanography 40, 766-778.

Diaz, R.J., Rosenberg, R., 2008. Spreading Dead Zones and Consequences for Marine Ecosystems. Science 321, 926-929. doi:10.1126/science.1156401

Dolédec, S., Chessel, D., Gimaret-Carpentier, C., 2000. Niche separation in community analysis: a new method. Ecology 81, 2914-2927.

Dray, S., Dufour, A.B., 2007. The ade4 package: implementing the duality diagram for ecologists. Journal of Statistical Software 22, 1-20.

Duong, T., 2007. ks: Kernel density estimation and kernel discriminant analysis for multivariate data in R. Journal of Statistical Software 21, 1-16.

Edwards, M., Richardson, A.J., 2004. Impact of climate change on marine pelagic phenology and trophic mismatch. Nature 430, 881-884. doi:10.1038/nature02808

Eppley, R.W., 1972. Temperature and phytoplankton growth in the sea. Fishery Bulletin 70, $1063-1085$.

Geange, S.W., Pledger, S., Burns, K.C., Shima, J.S., 2011. A unified analysis of niche overlap incorporating data of different types. Methods in Ecology and Evolution 2, 175-184. doi:10.1111/j.2041-210X.2010.00070.x

Gebühr, C., Wiltshire, K.H., Aberle, N., van Beusekom, J.E., Gerdts, G., 2009. Influence of nutrients, temperature, light and salinity on the occurrence of Paralia sulcata at Helgoland Roads, North Sea. Aquatic Biology 7, 185-197. 
Glé, C., Del Amo, Y., Sautour, B., Laborde, P., Chardy, P., 2008. Variability of nutrients and phytoplankton primary production in a shallow macrotidal coastal ecosystem (Arcachon Bay, France). Estuarine, Coastal and Shelf Science 76, 642-656. doi:10.1016/j.ecss.2007.07.043

Grossel, H., 2006. Manuel d'observation et de dénombrement du phytoplancton marin. Document de méthode REPHY. IFREMER, 43 pp.

Grüner, N., Gebühr, C., Boersma, M., Feudel, U., Wiltshire, K.H., Freund, J.A., 2011. Reconstructing the realized niche of phytoplankton species from environmental data: fitness versus abundance approach. Limnology Oceanography Methods 9, 432-442.

Guisan, A., Thuiller, W., 2005. Predicting species distribution: offering more than simple habitat models. Ecology Letters 8, 993-1009. doi:10.1111/j.1461-0248.2005.00792.x Hays, G.C., Richardson, A.J., Robinson, C., 2005. Climate change and marine plankton. Trends in Ecology \& Evolution 20, 337-344.

Heino, J., Soininen, J., 2006. Regional occupancy in unicellular eukaryotes: a reflection of niche breadth, habitat availability or size-related dispersal capacity? Freshwater Biology 51, 672-685. doi:10.1111/j.1365-2427.2006.01520.x

Helaouët, P., Beaugrand, G., Edwards, M., 2013. Understanding Long-Term Changes in Species Abundance Using a Niche-Based Approach. PLoS ONE 8, 1-9. doi : 10.1371/journal.pone.0079186

Hengl, T., Sierdsema, H., Radović, A., Dilo, A., 2009. Spatial prediction of species' distributions from occurrence-only records: combining point pattern analysis, ENFA and regression-kriging. Ecological Modelling 220, 3499-3511. doi:10.1016/j.ecolmodel.2009.06.038

Hernández-Fariñas, T., Soudant, D., Barillé, L., Belin, C., Lefebvre, A., Bacher, C., 2014. Temporal changes in the phytoplankton community along the French coast of the 
eastern English Channel and the southern Bight of the North Sea. ICES Journal of Marine Science 71, 821-833. doi:10.1093/icesjms/fst192

Houghton, J. T., Callander, B. A., Varney, S. K., 1992. Climate change 1992: The supplementary report to the IPCC scientific assessment. Intergovernmental Panel on Climate Change. Cambridge University Press, 200 pp.

Hutchinson, G.E., 1957. Concluding Remarks. Cold Spring Harb Symp Quant Biol 22, 415427. doi:10.1101/SQB.1957.022.01.039

Ifremer, Laboratoire Environnement Ressources d'Arcachon, 2013. Qualité du Milieu Marin Littoral Bulletin de la surveillance 2012. Départements: Gironde, Landes, Pyrénées Atlantiques. IFREMER, 127 pp.

Ifremer, Laboratoire Environnement Ressources Morbihan Pays de Loire, 2013. Qualité du Milieu Marin Littoral. Bulletin de la surveillance 2012. Département Morbihan. IFREMER, $127 \mathrm{pp}$.

Ignatiades, L., 1994. Species dominance and niche breadth in bloom and non-bloom phytoplankton populations. Oceanologica Acta 17, 89-96.

Irwin, A.J., Nelles, A.M., Finkel, Z.V., 2012. Phytoplankton niches estimated from field data. Limnology and Oceanography 57, 787-797.

Kiefer, D.A., Cullen, J.J., 1991. Phytoplankton growth and light absorption as regulated by light, temperature, and nutrients. Polar Research 10, 163-172. doi:10.1111/j.17518369.1991.tb00642.x

Koslow, J., Couture, J., 2013. Ocean sciences: Follow the fish. Nature 502, 163-164.

Kruk, C., Huszar, V.L.M., Peeters, E.T.H.M., Bonilla, S., Costa, L., Lürling, M., Reynolds, C.S., Scheffer, M., 2010. A morphological classification capturing functional variation in phytoplankton. Freshwater Biology 55, 614-627. doi:10.1111/j.13652427.2009.02298.x 
Lefebvre, A., Guiselin, N., Barbet, F., Artigas, F.L., 2011. Long-term hydrological and phytoplankton monitoring (1992-2007) of three potentially eutrophic systems in the eastern English Channel and the Southern Bight of the North Sea. ICES Journal of Marine Science 68: 2029-2043.

Lefebvre, K.A., Bargu, S., Kieckhefer, T., Silver, M.W., 2002. From sanddabs to blue whales: the pervasiveness of domoic acid. Toxicon 40, 971-977. doi:10.1016/S00410101(02)00093-4

Litchman, E., Edwards, K.F., Klausmeier, C.A., Thomas, M.K., 2012. Phytoplankton niches, traits and eco-evolutionary responses to global environmental change. Marine Ecology Progress Series 470, 235-248. doi:10.3354/meps09912

Litchman, E. and de Tezanos Pinto, P. Klausmeier, C. A. and Thomas, M. K. and Yoshiyama, K. 2010. Linking traits to species diversity and community structure in phytoplankton. Hydrobiologia $653: 15-28$.

Litchman, E., Klausmeier, C.A., 2008. Trait-Based Community Ecology of Phytoplankton. Annual Review of Ecology, Evolution, and Systematics 39, 615-639. doi:10.1146/annurev.ecolsys.39.110707.173549

Litchman, E., Klausmeier, C.A., Schofield, O.M., Falkowski, P.G., 2007. The role of functional traits and trade-offs in structuring phytoplankton communities: scaling from cellular to ecosystem level. Ecology Letters 10, 1170-1181. doi:10.1111/j.14610248.2007.01117.x

Litchman, E., Steiner, D., Bossard, P., 2003. Photosynthetic and growth responses of three freshwater algae to phosphorus limitation and daylength. Freshwater Biology 48, 2141-2148. doi:10.1046/j.1365-2427.2003.01157.x

Manabe, T., Ishio, S., 1991. Bloom of Coscinodiscus wailesii and DO deficit of bloom water in Seto Inland Sea. Marine Pollution Bulletin 23:181-184. 
Margalef, R., 1978. Life-forms of phytoplankton as survival alternatives in an unstable environment. Oceanologica Acta 1 : 493-509.

Méléder, V., Barillé-Boyer, A.L., Baud, J.P., Barillé, L., Cognie, B., Rosa, P., 2001. Modélisation de l'affinage de l'huître Crassostrea gigas alimentée avec la diatomée Skeletonema costatum. Aquat Living Resour 14, 1-16.

Michel, S., Vandermeirsch, F., Lorance, P., 2009. Evolution of upper temperature in the Bay during the last 40 years. Aquat Living Resour 22, 447-461.

Mouillot, D., Stubbs, W., Faure, M., Dumay, O., Tomasini, J.A., Wilson, J.B., Chi, T.D., 2005. Niche overlap estimates based on quantitative functional traits: a new family of non-parametric indices. Oecologia 145, 345-353. doi:10.1007/s00442-005-0151-z

Nagai, S., Hori, Y., Manabe, T., Imai, I., 1995. Restoration of cell size by vegetative cell enlargement in Coscinodiscus wailesii (Bacillariophyceae). Phycologia 34, 533-535.

Nehring, S., 1998. Establishment of thermophilic phytoplankton species in the North Sea: biological indicators of climatic changes? ICES Journal of Marine Science 55, 818823.

Oksanen, J., Blanchet, G. F., Kindt, R., Legendre, P., Minchin, P. R., O'Hara, R. B., Simpson, G. L., Solymos, P., Stevens, M. H., Wagner, H., 2014. vegan: Community Ecology Package. R package version 2.2-0. http://CRAN.R-project.org/package=vegan

Olenina, I., Wasmund, N., Hajdu, S., Jurgensone, I., Gromisz, S., Kownacka, J., Toming, K., Vaiciūtè, D., Olenin, S., 2010. Assessing impacts of invasive phytoplankton: The Baltic Sea case. Marine Pollution Bulletin 60, 1691-1700.

Pearman, P.B., Guisan, A., Broennimann, O., Randin, C.F., 2008. Niche dynamics in space and time. Trends in Ecology \& Evolution 23, 149-158. doi:10.1016/j.tree.2007.11.005 
Pradervand, J-N., Pellissier, L., Randin, C., Guisan, A., 2014. Functional homogenization of bumblebee communities in alpine landscapes under projected climate change. Climate Change Responses $1: 1-10$.

R Core Team, 2013. R: A Language and Environment for Statistical Computing. R Foundation for Statistical Computing, Vienna, Austria.

Reynolds, C. S., 2006. Ecolology of phytoplankton. Cambridge University Press, London. $535 \mathrm{pp}$.

Ribeiro, L., Brotas, V., Rincé, Y., Jesus, B., 2013. Structure and diversity of intertidal benthic diatom assemblages in contrasting shores: a case study from the Tagus estuary. Journal of Phycology 49, 258-270. doi:10.1111/jpy.12031

Round, F.E., Crawford, R.M., Mann, D.G., 1990. The Diatoms: Biology \& Morphology of the Genera. Cambridge University Press, Cambridge, 747 pp.

Roweis, S., 1998. EM algorithms for PCA and SPCA, Proceedings of the 1997 conference on Advances in neural information processing systems 10, 626-632, Denver, Colorado, USA.

Sabbe, K., Vyverman, W., Muylaert, K., 1999. New and little-known Fallacia species (Bacillariophyta) from brackish and marine intertidal sandy sediments in Northwest Europe and North America. Phycologia 38, 8-22. doi:10.2216/i0031-8884-38-1-8.1

Scheffer, M., Rinaldi, S., Huisman, J., Weissing, F. J., 2003. Why plankton communities have no equilibrium: solutions to the paradox. Hydrobiologia, 491: 9-18.

Schoener, T.W., 1968. The Anolis lizards of Bimini: resource partitioning in a complex fauna. Ecology 49, 704-726.

Schoener, T.W., 1970. Nonsynchronous spatial overlap of lizards in patchy habitats. Ecology 51, 408-418. doi:10.2307/1935376 
Sellner, K.G., Doucette, G.J., Kirkpatrick, G.J., 2003. Harmful algal blooms: causes, impacts and detection. Journal of Industrial Microbiology and Biotechnology 30, 383-406. doi:10.1007/s10295-003-0074-9

Siano, R., 2007. The phytoplankton of the Campania coast: an ecological and taxonomic study. Ph. D. Thesis, University of Messina, Italy, unpublished.

Smayda, T. J., Reynolds, C. S., 2001. Community Assembly in Marine Phytoplankton: Application of Recent Models to Harmful Dinoflagellate Blooms. Journal of Plankton Research 23: 447-461.

Stacklies, W., Redestig, H., Scholz, M., Walther, D., Selbig, J., 2007. pcaMethods-a bioconductor package providing PCA methods for incomplete data. Bioinformatics 23, 1164-1167. doi:10.1093/bioinformatics/btm069

Thornton, D.C.O., Dong, L.F., Underwood, G.J.C., Nedwell, D.B., 2002. Factors affecting microphytobenthic biomass, species composition and production in the Colne Estuary (UK). Aquatic Microbial Ecology 27, 285-300. doi:10.3354/ame027285

Thuiller, W., Gassó, N., Pino, J., Vilà, M., 2012. Ecological niche and species traits: key drivers of regional plant invader assemblages. Biological Invasions 14, 1963-1980. doi:10.1007/s10530-012-0206-0

Underwood, G., Phillips, J., Saunders, K., 1998. Distribution of estuarine benthic diatom species along salinity and nutrient gradients. European Journal of Phycology 33, 173183. doi:10.1080/09670269810001736673

Underwood, G.J.C., 1994. Seasonal and Spatial Variation in Epipelic Diatom Assemblages in the Severn Estuary. Diatom Research 9, 451-472.

doi:10.1080/0269249X.1994.9705319 
Vested, H.J., Tessier, C., Christensen, B.B., Goubert, E., 2013. Numerical modelling of morphodynamics_-Vilaine Estuary. Ocean Dynamics 63, 423-446. doi:10.1007/s10236-013-0603-7

Warren, D.L., Glor, R.E., Turelli, M., 2008. Environmental Niche Equivalency Versus Conservatism: Quantitative Approaches to Niche Evolution. Evolution 62, 28682883. doi:10.1111/j.1558-5646.2008.00482.x

Warton, D.I., Hui, F.K.C., 2006. The arcsine is asinine: the analysis of proportions in ecology. Ecology 92, 3-10.

Figure Legends

Figure 1. Location of the six sampling sites of the REPHY network used in this study. Three geographical areas are highlighted: (A) eastern English Channel and Southern Bight of the North Sea, (B) South of Brittany, Atlantic ocean and (C) Arcachon Bay, Atlantic ocean.

Figure 2. Kernel density estimation associated with Leptocylindrus occurrences. (A) 3dimensional histogram of Leptocylindrus genus occurrences along the first and secondary axis of the OMI, representing the environmental space of the entire datasets. Bars represent the number of occurrences of the genus Leptocylindrus at each cell of the $r \mathrm{x} r$ grid ( $r$ was set at 100). Minimum and maximum values for the grid were defined by the bounded coordinates of the OMI. (B) Corresponding kernel density estimate along the first two axes of the OMI.

Figure 3. Outlying Mean Index (OMI) analysis of 35 phytoplankton taxonomic units. (A) Canonical weights of the seven environmental factors plus the two biotic parameters used in 
this study to characterize the ecological niche of phytoplankton units (TEMP = water temperature, $\mathrm{PAR}=$ photosynthetically active radiation, $\mathrm{TURB}=$ turbidity, $\mathrm{SALI}=$ salinity, $\mathrm{SIOH}=$ silicates, $\mathrm{DIN}=$ dissolved inorganic nitrogen, $\mathrm{PO} 4=$ phosphates, $\mathrm{S}=$ number of taxonomic units in the sample unit, $\mathrm{BP}=$ Berger-Parker index $).(B, C)$ Space occupied by the genera Leptocylindrus and Skeletonema along the first and second axes of the OMI analysis. The yellow-to-red color gradient represents the density from low to high, respectively. (D) Taxa distribution according to their weighted average position (here a single axis representation was used, corresponding to the first axis). The diameter of the circle is proportional to the total occurrence frequency of each taxonomic unit and vertical lines represent the niche breadth ( \pm 2 tolerance index). The inertia explained by the first two axes is $85.1 \%$. For the corresponding codes of taxa see Table 1.

Figure 4. Non-metric multidimensional scaling (nMDS) of taxonomic units distance based on the (1-D) matrix. Segments are drawn to connect taxonomic units having similar niches based on the similarity test. For the corresponding codes of taxa see Table 1.

Figure 5. Relationship between (A) marginality and tolerance and (B, C) occurrence frequency and niche parameters. Codes with black labels represent points with a large Cook distance and excluded from the linear regression analysis (see DAC, CER and SKE). Figure 6. Relationship between the measures of niche overlap and niche parameters. For each taxonomic unit, the median value of the combinations of overlap was represented. The size of the taxonomic code label represents the standard deviations of the measured overlaps. The code with black label represents the point with a large Cook distance and excluded from the linear regression analysis (see PHA). 
Table 1. List of the 35 phytoplankton taxonomic units used for the niche analysis.

\begin{tabular}{|c|c|c|}
\hline Group & Code & Species \\
\hline \multirow[t]{20}{*}{ Diatoms } & AST & $\begin{array}{l}\text { Asterionella sp, A. formosa, Asterionellopsis sp, mainly A. glacialis, } \\
\text { Asteroplanus, A. karianus }\end{array}$ \\
\hline & $B I D$ & Biddulphia sp, mainly B. rhombus, Trigonium alternans \\
\hline & CER & Cerataulina sp, mainly $C$. pelagica \\
\hline & CHA & 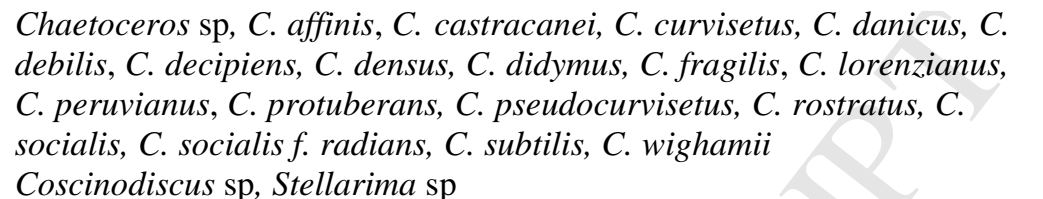 \\
\hline & $D A C$ & Dactyliosolen sp, mainly D. fragilissimus \\
\hline & $D I T$ & Ditylum sp, mainly $D$. brightwellii \\
\hline & EUC & Eucampia sp, mainly E. zodiacus, Climacodium $\mathrm{sp}$ \\
\hline & GUI & Guinardia sp, G. flaccida, mainly G. striata and G. delicatula \\
\hline & $L A U$ & Lauderia sp, L. annulata, Schroederella sp \\
\hline & $L E P$ & Leptocylindrus sp, L. danicus, L. curvatus, L. minimus \\
\hline & $N A V$ & $\begin{array}{l}\text { Navicula } \mathrm{sp}, \text { N. cryptocephala, N. gregaria, N. pelagica, Fallacia sp, } \\
\text { Haslea sp, H. wawrikae, Lyrella sp, Petroneis sp }\end{array}$ \\
\hline & NIT & Nitzschia sp, mainly N. longissima, Hantzschia sp \\
\hline & $O D O$ & $\begin{array}{l}\text { Odontella sp, } O \text {. aurita, O. granulata, O. mobiliensis, } O \text {. regia, } O \text {. } \\
\text { Sinensis }\end{array}$ \\
\hline & PARs & Paralia sulcata \\
\hline & PLE & Pleurosigma sp, Gyrosigma sp \\
\hline & $P S E$ & Pseudo-nitzschia spp \\
\hline & RHI & $\begin{array}{l}\text { Rhizosolenia sp, } R \text {. hebetata, } R \text {. imbricata, } R \text {. styliformis, } R \text {. setigera, } R \text {. } \\
\text { setigera f. pungens, Neocalyptrella robusta }\end{array}$ \\
\hline & SKE & Skeletonema sp, mainly Skeletonema costatum \\
\hline & $T H P$ & $\begin{array}{l}\text { Thalassiosira sp, } T \text {. angulata, } T \text {. antarctica, } T . \text { gravida, } T . \text { levanderi, } T \text {. } \\
\text { minima, } T \text {. nordenskioeldii, } T \text {. rotula, } T . \text { subtilis, Porosira } \mathrm{sp}\end{array}$ \\
\hline & $T H L$ & Thalassionema sp, mainly T. nitzschioides, Thalassiothrix sp, Lioloma sp \\
\hline \multirow[t]{12}{*}{ Dinoflagellates } & $A L E$ & $\begin{array}{l}\text { Alexandrium sp, A. margalefii, A. minutum, A. ostenfeldii, A. } \\
\text { pseudogonyaulax }\end{array}$ \\
\hline & CEI & $\begin{array}{l}\text { Ceratium sp, mainly Neoceratium furca and } N . \text { fusus, } N \text {. lineatum, } N \text {. } \\
\text { minutum, N. tripos }\end{array}$ \\
\hline & $D I P$ & $\begin{array}{l}\text { Diplopsalis sp, Diplopelta sp, Diplopsalopsis sp, Preperidinium sp, } \\
\text { Oblea } \mathrm{sp}\end{array}$ \\
\hline & GON & Gonyaulax sp, mainly G. spinifera, G. verior \\
\hline & $G Y M$ & Gymnodinium sp, G. catenatum, Gyrodinium sp, G. spirale \\
\hline & $H E T$ & Heterocapsa sp, H. niei, H. triquetra \\
\hline & $K A T$ & Katodinium $\mathrm{sp}$ \\
\hline & NOC & Noctiluca scintillans \\
\hline & $P O L$ & Polykrikos sp, P. schwarzii \\
\hline & $P R O$ & $\begin{array}{l}\text { Prorocentrum } \mathrm{sp}, P . \text { arcuatum, } P . \text { balticum, } P . \text { cordatum, } P . \\
\text { compressum, } P . \text { gibbosum, } P . \text { gracile, } P . \text { micans, } P \text {. triestinum }\end{array}$ \\
\hline & $P R P$ & $\begin{array}{l}\text { Protoperidinium sp, mainly } P \text {. bipes, } P . \text { conicum, } P \text {. depressum, } P \text {. } \\
\text { diabolum, } P \text {. longipes, } P \text {. steinii, } P \text {. pyriforme, Archaeperidinium } \\
\text { minutum, Peridinium sp, } P \text {. quiquecorne }\end{array}$ \\
\hline & $S C R$ & $\begin{array}{l}\text { mainly Scrippsiella sp, Ensiculifera sp, Pentapharsodinium sp, } \\
\text { Bysmatrum sp }\end{array}$ \\
\hline Haptophyta & PHA & Phaeocystis sp \\
\hline Silicoflagellates & $D I C$ & Dictyocha sp, D. speculum \\
\hline
\end{tabular}


Table 2. Principal characteristics of the sampling sites used in this study. See Fig. 1 for location of sites. Values of river flow represent the annual mean.

\begin{tabular}{|c|c|c|c|c|c|c|}
\hline$\overline{\text { Site }}$ & Geographical area & $\begin{array}{l}\text { Longitude } \\
\left({ }^{\circ} \mathrm{E}\right)\end{array}$ & $\begin{array}{l}\text { Latitude } \\
\left({ }^{\circ} \mathrm{N}\right)\end{array}$ & $\begin{array}{l}\text { Distance to } \\
\text { coast }(\mathrm{km})\end{array}$ & $\begin{array}{c}\text { Main river } \\
\text { near site }\end{array}$ & $\begin{array}{c}\text { River flow } \\
\left(\mathrm{m}^{3} \mathrm{~s}^{-1}\right)\end{array}$ \\
\hline Dunkerque & $\begin{array}{l}\text { Southern Bight of } \\
\text { the North Sea }\end{array}$ & 2.33 & 51.07 & 1.4 & Aa & 10 \\
\hline Boulogne & English Channel & 1.55 & 50.75 & 3.1 & Liane & 3 \\
\hline Somme & English Channel & 1.47 & 50.23 & 3.9 & Somme & 35 \\
\hline Men er Roue & Atlantic ocean & -3.09 & 47.53 & 2.8 & Vilaine & 70 \\
\hline Ouest Loscolo & Atlantic ocean & -2.54 & 47.46 & 2.9 & Vilaine & 70 \\
\hline Teychan & Atlantic ocean & -1.16 & 44.67 & 0.9 & Leyre & 19 \\
\hline
\end{tabular}

See Figure 1 for location of sites. Values of river flow represent the annual mean.

Table 3. Main environmental conditions of the studied sites.

\begin{tabular}{|c|c|c|c|c|c|c|c|c|}
\hline Site & $\begin{array}{c}\text { Chl } a \\
\left(\mu \mathrm{g} \mathrm{L}^{-1}\right)\end{array}$ & $\begin{array}{l}\text { TEMP } \\
\left({ }^{\circ} \mathrm{C}\right)\end{array}$ & $\begin{array}{c}\text { PAR } \\
\left(10^{3} \mathrm{~W} \mathrm{~m}^{-2}\right) \\
\end{array}$ & SALI & $\begin{array}{l}\text { TURB } \\
\text { (NTU) }\end{array}$ & $\begin{array}{c}\text { DIN } \\
\left(\mu \mathrm{mol} \mathrm{L}^{-1}\right)\end{array}$ & $\begin{array}{c}\text { SIOH } \\
\left(\mu \mathrm{mol} \mathrm{L}{ }^{-1}\right)\end{array}$ & $\begin{array}{c}\mathrm{PO} 4 \\
\left(\mu \mathrm{mol} \mathrm{L}{ }^{-1}\right)\end{array}$ \\
\hline$\overline{\text { Dunk }}$ & $\begin{array}{c}4.6 \\
(2.5-8.7)\end{array}$ & $\begin{array}{c}12.1 \\
(8.2-16.9)\end{array}$ & $\begin{array}{c}2.4 \\
(1.1-4.6)\end{array}$ & $\begin{array}{c}34 \\
(33.5-34.6)\end{array}$ & $\begin{array}{c}4.5 \\
2.6-7.8)(\end{array}$ & $\begin{array}{c}5 \\
(1.3-17.7)\end{array}$ & $\begin{array}{c}3.9 \\
(1.2-7.5)\end{array}$ & $\begin{array}{c}0.5 \\
(0.2-0.8)\end{array}$ \\
\hline Boul & $\begin{array}{c}4 \\
(2.2-9.1)\end{array}$ & $\begin{array}{c}11.7 \\
(8.6-16.2)\end{array}$ & $\begin{array}{c}2.5 \\
(1.2-4.7)\end{array}$ & $\begin{array}{c}34 \\
(33.5-34.5)\end{array}$ & $\begin{array}{c}2.7 \\
(1.5-4.5)(\end{array}$ & $\begin{array}{c}4.8 \\
(1.5-13.6)\end{array}$ & $\begin{array}{c}2.1 \\
(0.6-5.2)\end{array}$ & $\begin{array}{c}0.3 \\
(0.2-0.7)\end{array}$ \\
\hline Somme & $\begin{array}{c}6.4 \\
(3.2-11.9)\end{array}$ & $\begin{array}{c}13.3 \\
(9.1-17.4)\end{array}$ & $\begin{array}{c}2.5 \\
(1.2-4.5)\end{array}$ & $\begin{array}{c}33.2 \\
(32.5-33.7)\end{array}$ & $\begin{array}{c}4.5 \\
(3.1-9)\end{array}$ & $\begin{array}{c}9.3 \\
(2.5-21.9)\end{array}$ & $\begin{array}{c}3.1 \\
(0.9-9.7)\end{array}$ & $\begin{array}{c}0.3 \\
(0.1-0.6)\end{array}$ \\
\hline Men & $\begin{array}{c}1.2 \\
(0.9-2)\end{array}$ & $\begin{array}{c}13.6 \\
(10.2-16.9)\end{array}$ & $\begin{array}{c}2.7 \\
(1.5-4.9)\end{array}$ & $\begin{array}{c}34 \\
(32.9-34.6)\end{array}$ & $\begin{array}{c}1.9 \\
(1.2-3.6)\end{array}$ & $\begin{array}{c}7.1 \\
(1.1-21.4)\end{array}$ & $\begin{array}{c}8 \\
(3.6-17.2)\end{array}$ & $\begin{array}{c}0.3 \\
(0.1-0.5)\end{array}$ \\
\hline Oues & $\begin{array}{c}3.2 \\
(1.5-6)\end{array}$ & $\begin{array}{c}14.3 \\
(10.3-17.6)\end{array}$ & $\begin{array}{c}2.6 \\
(1.4-4.7)\end{array}$ & $\begin{array}{c}32.3 \\
(30.6-33 .\end{array}$ & $\begin{array}{c}4.2 \\
2.3-7.4)(\end{array}$ & $\begin{array}{c}16.7 \\
(2.8-40.4)\end{array}$ & $\begin{array}{c}14.9 \\
(6.5-26.1)\end{array}$ & $\begin{array}{c}0.3 \\
(0.2-0.7)\end{array}$ \\
\hline Teychan & $\begin{array}{c}1.9 \\
(1.4-2.6) \\
\end{array}$ & $\begin{array}{c}15.3 \\
(11-19.6) \\
\end{array}$ & $\begin{array}{c}3 \\
(1.7-5.2) \\
\end{array}$ & $\begin{array}{c}33.3 \\
(31.8-34.2) \\
\end{array}$ & $\begin{array}{c}1.5 \\
(1.1-2.2) \\
\end{array}$ & $\begin{array}{c}4.8 \\
(1.7-11) \\
\end{array}$ & $\begin{array}{c}7.8 \\
(5.2-12) \\
\end{array}$ & $\begin{array}{c}0.1 \\
(0.07-0.15\end{array}$ \\
\hline
\end{tabular}

Median values are indicated (lower and upper quartile in parentheses). See Fig. 1 for location of sites. Chl $a$ : chlorophyll $a$, TEMP: water temperature, PAR: photosynthetically active radiation, SALI: salinity, TURB: turbidity, DIN: dissolved inorganic nitrogen, SIOH: silicates and PO4: phosphates. 
Table 4. Niche parameters of the phytoplankton units analyzed in this study.

\begin{tabular}{|c|c|c|c|c|c|c|c|c|}
\hline Code & Inertia & Marg & Tol & Rtol & Marg\% & Tol\% & Rtol\% & $\begin{array}{l}\text { Occurrence } \\
\text { frequency }\end{array}$ \\
\hline$D A C$ & 6.64 & 2.04 & 0.93 & 3.67 & 30.7 & 14 & 55.3 & 22.5 \\
\hline PHA & 7.49 & 1.56 & 0.75 & 5.19 & 20.8 & 9.9 & 69.2 & 12 \\
\hline CER & 6.55 & 1.45 & 1.12 & 3.98 & 22.1 & 17.1 & 60.8 & 33.2 \\
\hline EUC & 6.44 & 1.25 & 0.99 & 4.2 & 19.4 & 15.3 & 65.2 & 17.3 \\
\hline NOC & 7.13 & 1.24 & 1.28 & 4.61 & 17.4 & 17.9 & 64.7 & 9.2 \\
\hline$K A T$ & 6.58 & 1.07 & 0.94 & 4.57 & 16.2 & 14.2 & 69.5 & 16.9 \\
\hline$A L E$ & 7.42 & 0.97 & 1.87 & 4.57 & 13.1 & 25.3 & 61.6 & 13.4 \\
\hline GON & 8.16 & 0.93 & 1.15 & 6.08 & 11.4 & 14.1 & 74.5 & 14.4 \\
\hline LEP & 7.27 & 0.81 & 1.95 & 4.51 & 11.2 & 26.8 & 62.1 & 58.9 \\
\hline DIP & 6.93 & 0.81 & 1.39 & 4.73 & 11.6 & 20.1 & 68.3 & 25.7 \\
\hline CEI & 7.29 & 0.79 & 1.49 & 5.01 & 10.9 & 20.4 & 68.7 & 29.6 \\
\hline$P O L$ & 8.93 & 0.7 & 1.02 & 7.22 & 7.8 & 11.4 & 80.8 & 12.1 \\
\hline ODO & 9.32 & 0.66 & 1.64 & 7.01 & 7.1 & 17.7 & 75.3 & 25.2 \\
\hline$H E T$ & 10.37 & 0.52 & 0.95 & 8.9 & 5 & 9.2 & 85.8 & 22.5 \\
\hline PRO & 7.4 & 0.52 & 1.91 & 4.98 & 7.1 & 25.7 & 67.2 & 51.4 \\
\hline$B I D$ & 8.32 & 0.51 & 1.68 & 6.13 & 6.1 & 20.2 & 73.7 & 25 \\
\hline DIT & 8.93 & 0.5 & 1.64 & 6.78 & 5.6 & 18.4 & 76 & 42.8 \\
\hline GUI & 6.69 & 0.48 & 1.64 & 4.58 & 7.1 & 24.5 & 68.4 & 70 \\
\hline$L A U$ & 7.57 & 0.45 & 0.66 & 6.46 & 5.9 & 8.8 & 85.3 & 20.8 \\
\hline PSE & 6.84 & 0.45 & 1.62 & 4.77 & 6.6 & 23.7 & 69.8 & 71.6 \\
\hline $\cos$ & 9.14 & 0.4 & 2.39 & 6.34 & 4.4 & 26.2 & 69.4 & 31 \\
\hline RHI & 7 & 0.39 & 1.84 & 4.77 & 5.6 & 26.3 & 68.1 & 68 \\
\hline$S C R$ & 8.74 & 0.39 & 1.53 & 6.82 & 4.5 & 17.5 & 78 & 47.7 \\
\hline PARs & 9.53 & 0.34 & 2.27 & 6.91 & 3.6 & 23.9 & 72.5 & 54.7 \\
\hline SKE & 10.24 & 0.33 & 3.57 & 6.34 & 3.2 & 34.8 & 61.9 & 47.6 \\
\hline$P R P$ & 7.7 & 0.3 & 2.29 & 5.11 & 3.9 & 29.7 & 66.4 & 70.5 \\
\hline$D I C$ & 7.7 & 0.27 & 0.81 & 6.62 & 3.5 & 10.6 & 86 & 33.9 \\
\hline CHA & 7.33 & 0.26 & 1.84 & 5.22 & 3.5 & 25.1 & 71.3 & 67.6 \\
\hline$A S T$ & 8.41 & 0.25 & 0.9 & 7.26 & 2.9 & 10.7 & 86.4 & 45.5 \\
\hline$T H P$ & 8.97 & 0.22 & 1.95 & 6.8 & 2.5 & 21.7 & 75.8 & 62.6 \\
\hline NAV & 8.77 & 0.2 & 1.08 & 7.49 & 2.3 & 12.3 & 85.4 & 46.4 \\
\hline$T H L$ & 8.42 & 0.17 & 0.93 & 7.31 & 2.1 & 11.1 & 86.8 & 51.2 \\
\hline PLE & 8.88 & 0.12 & 1.14 & 7.62 & 1.3 & 12.9 & 85.8 & 54.6 \\
\hline$G Y M$ & 7.89 & 0.1 & 2.61 & 5.18 & 1.3 & 33 & 65.6 & 73.6 \\
\hline $\mathrm{NI}$ & 8.54 & 0.06 & 1.45 & 7.03 & 0.7 & 16.9 & 82.4 & 74.6 \\
\hline
\end{tabular}

Marg (Marginality), Tol (Tolerance), Rtol (Residual Tolerance) and corresponding values in $\%$. For codes of phytoplankton units, refer to Table 1. Bold labels for diatoms.

Supplementary material:

Figure S1. Seasonal patterns of environmental variables at six sampling sites along the French coast of the English Channel, the Southern Bight of the North Sea and the Atlantic Ocean.

Each dot represents the median value for each month between 1999 and 2012. Abbreviations 
of environmental variables: Chl a (chlorophyll $a$ ), PAR (photosynthetically active radiation), TEMP (water temperature), SALI (salinity), TURB (turbidity), SIOH (silicates), DIN (dissolved inorganic nitrogen), PO4 (phosphates). Left and right scales for black and gray lines, respectively.

Figure S2. Weighted average position of the 35 phytoplankton units considered in this study for the Outlying Mean Index analysis (OMI). Niche positions are proportional to the OMI index for each taxonomic unit (see Table 4). First and second axes of the OMI analysis represent $85.1 \%$ of the explained variance. For codes corresponding to the taxa, see Table 1. 


\section{ACCEPTED MANUSCRIPT}
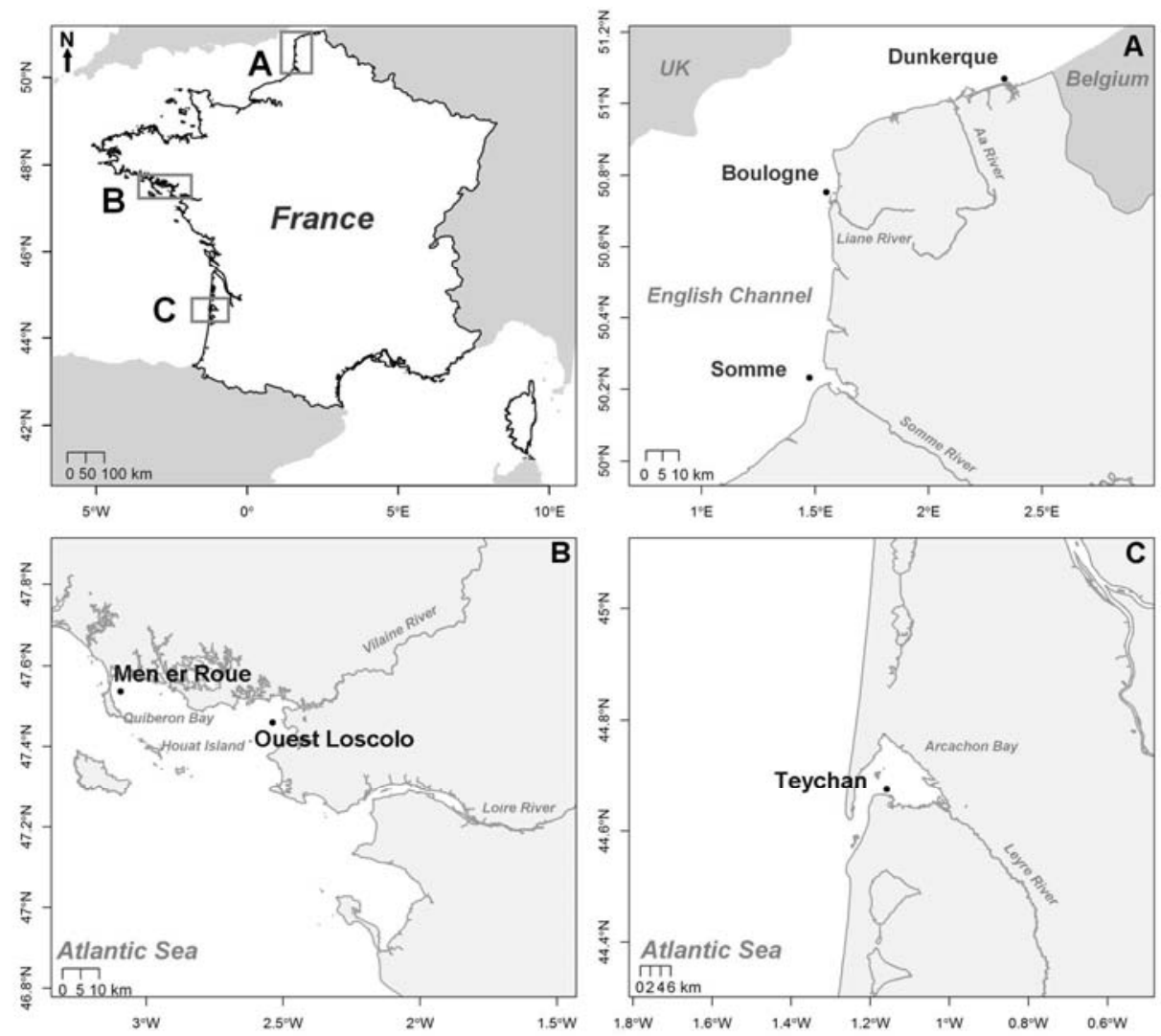

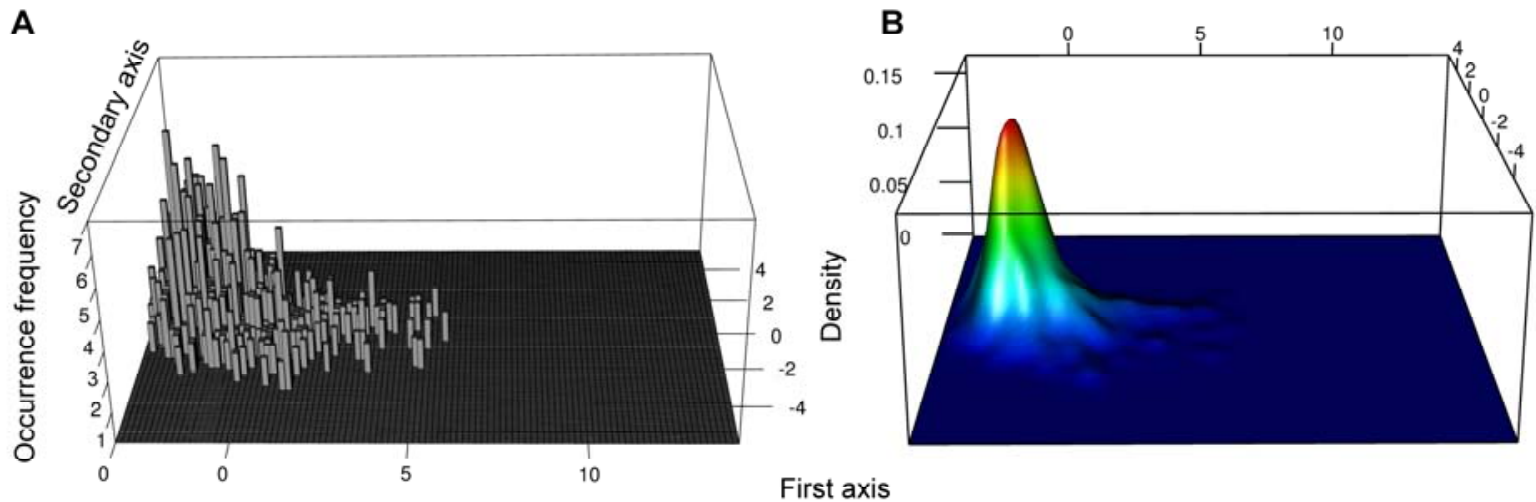


\section{A}
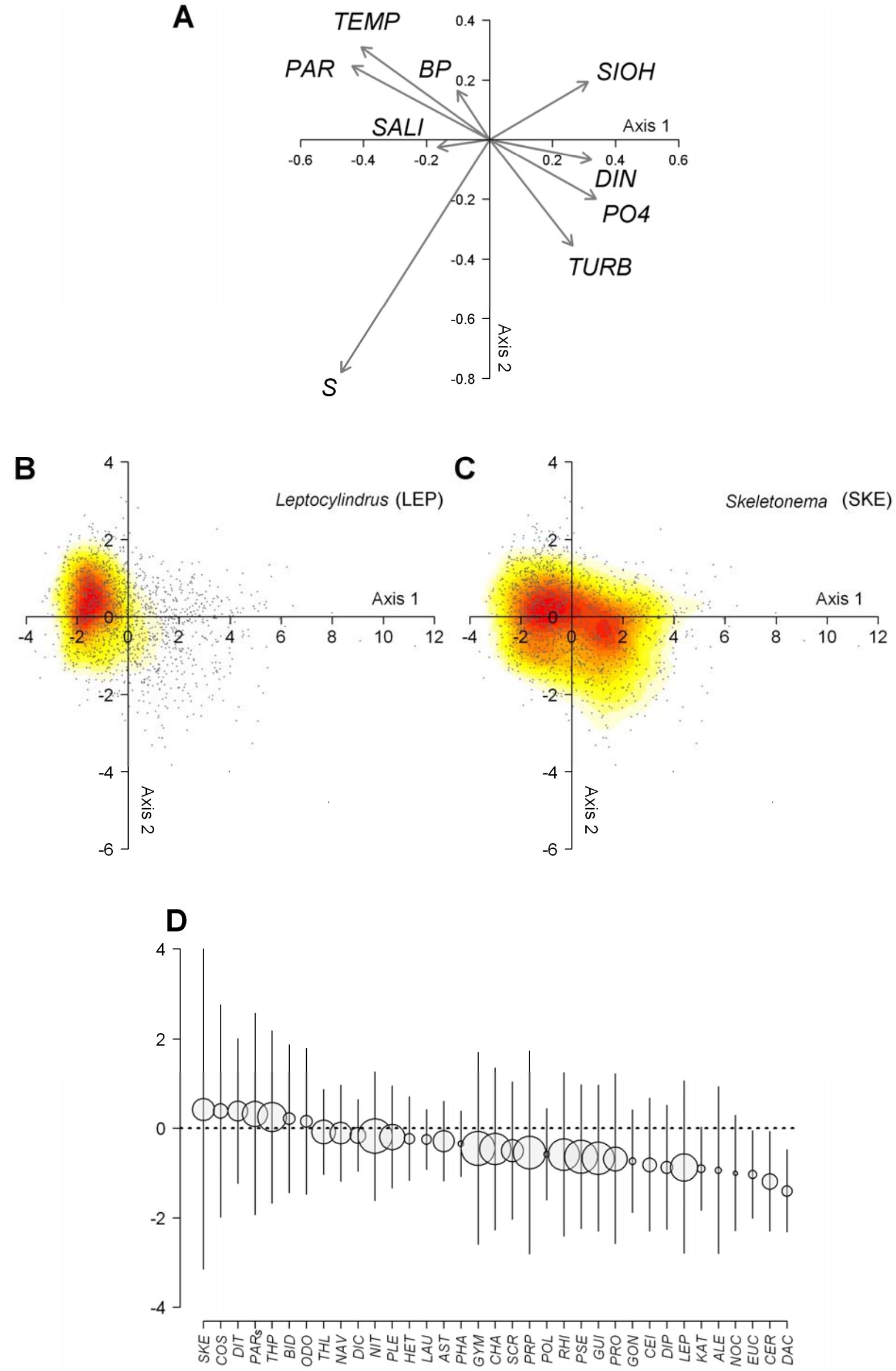


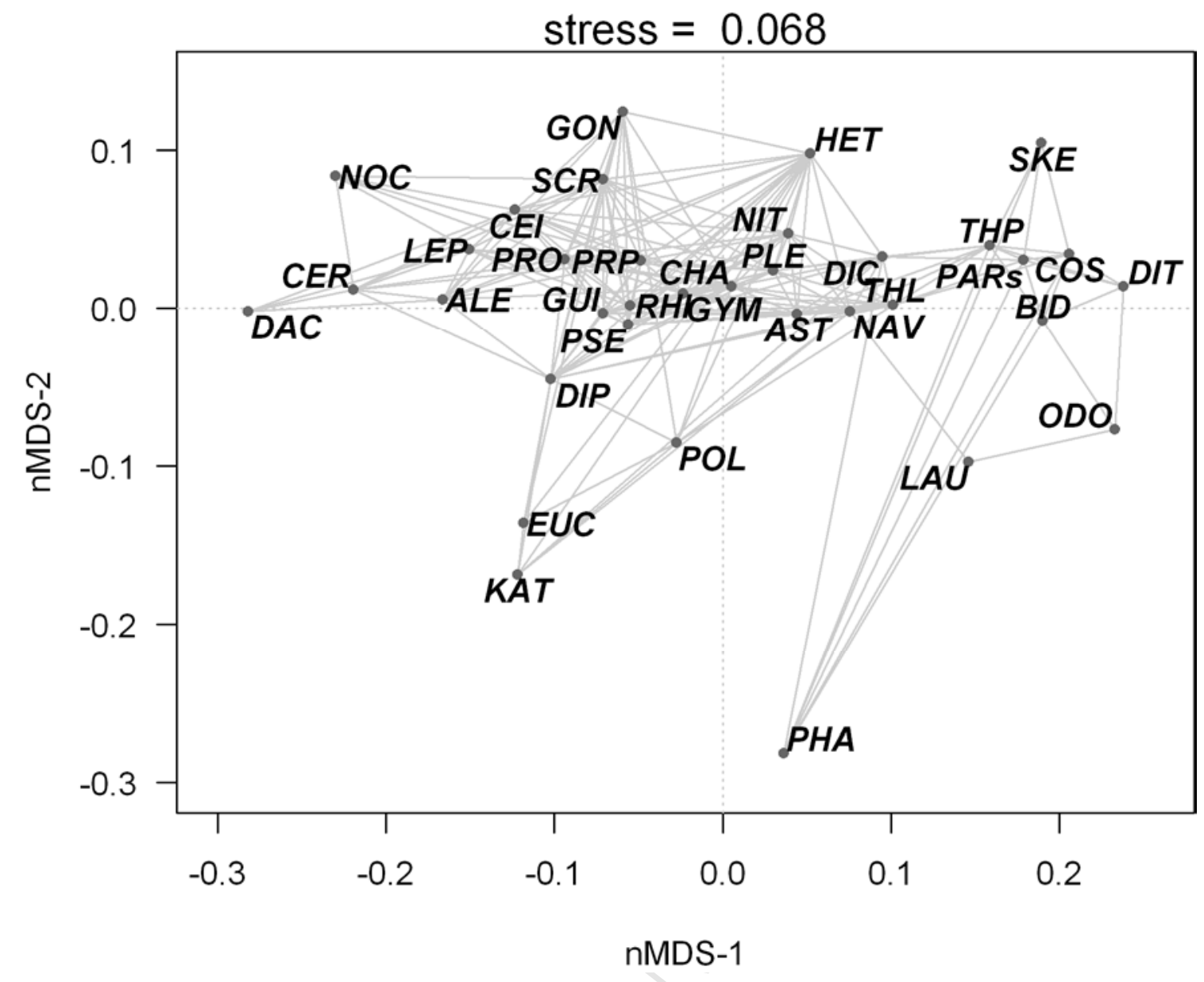




\section{ACCEPTED MANUSCRIPT}
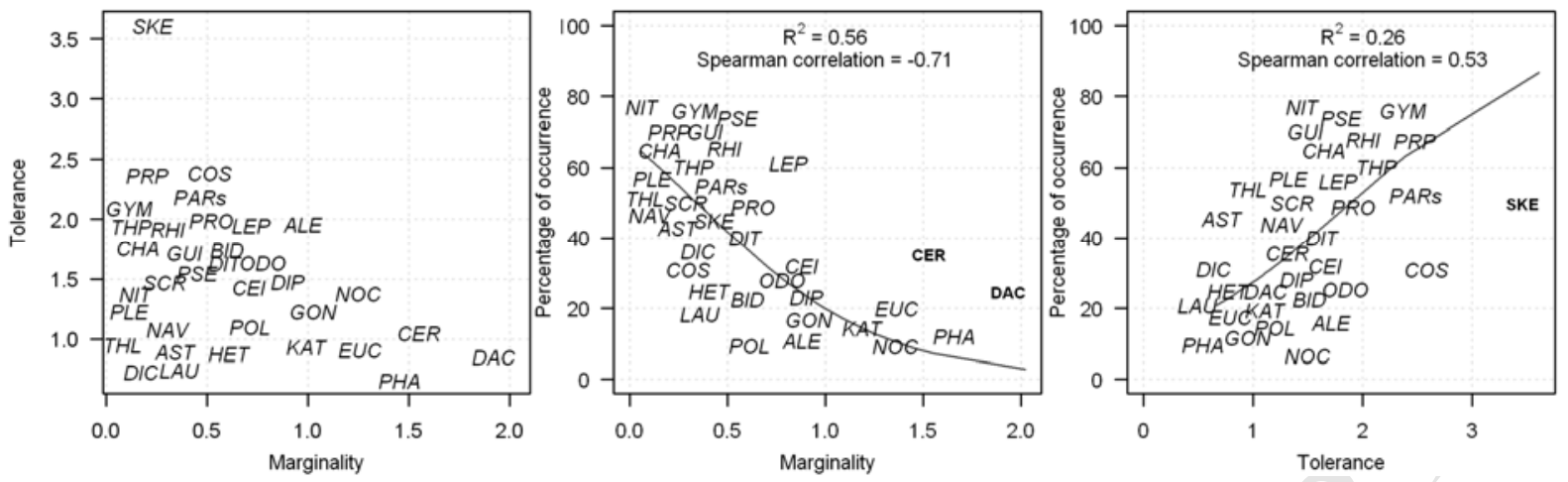

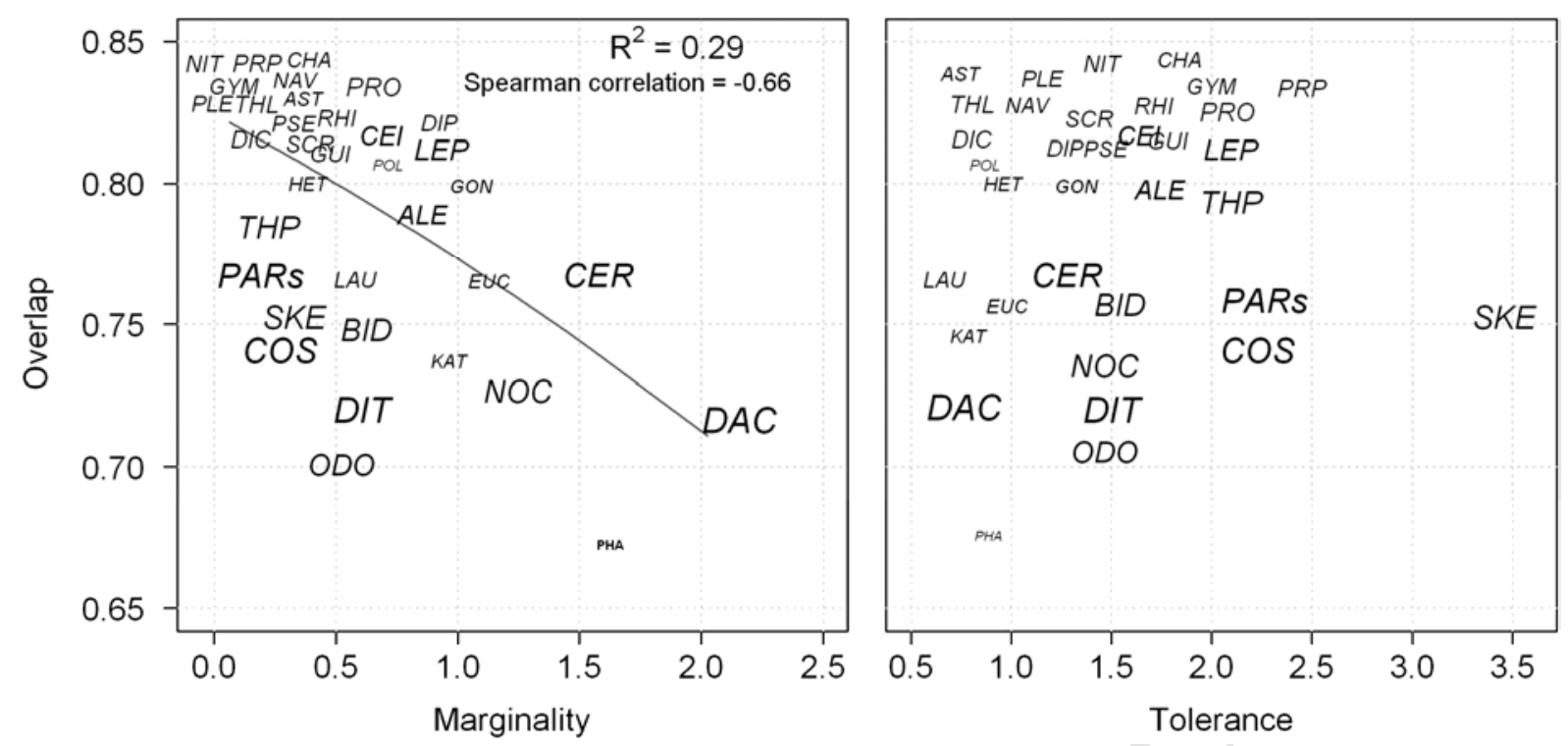


\section{ACCEPTED MANUSCRIPT}
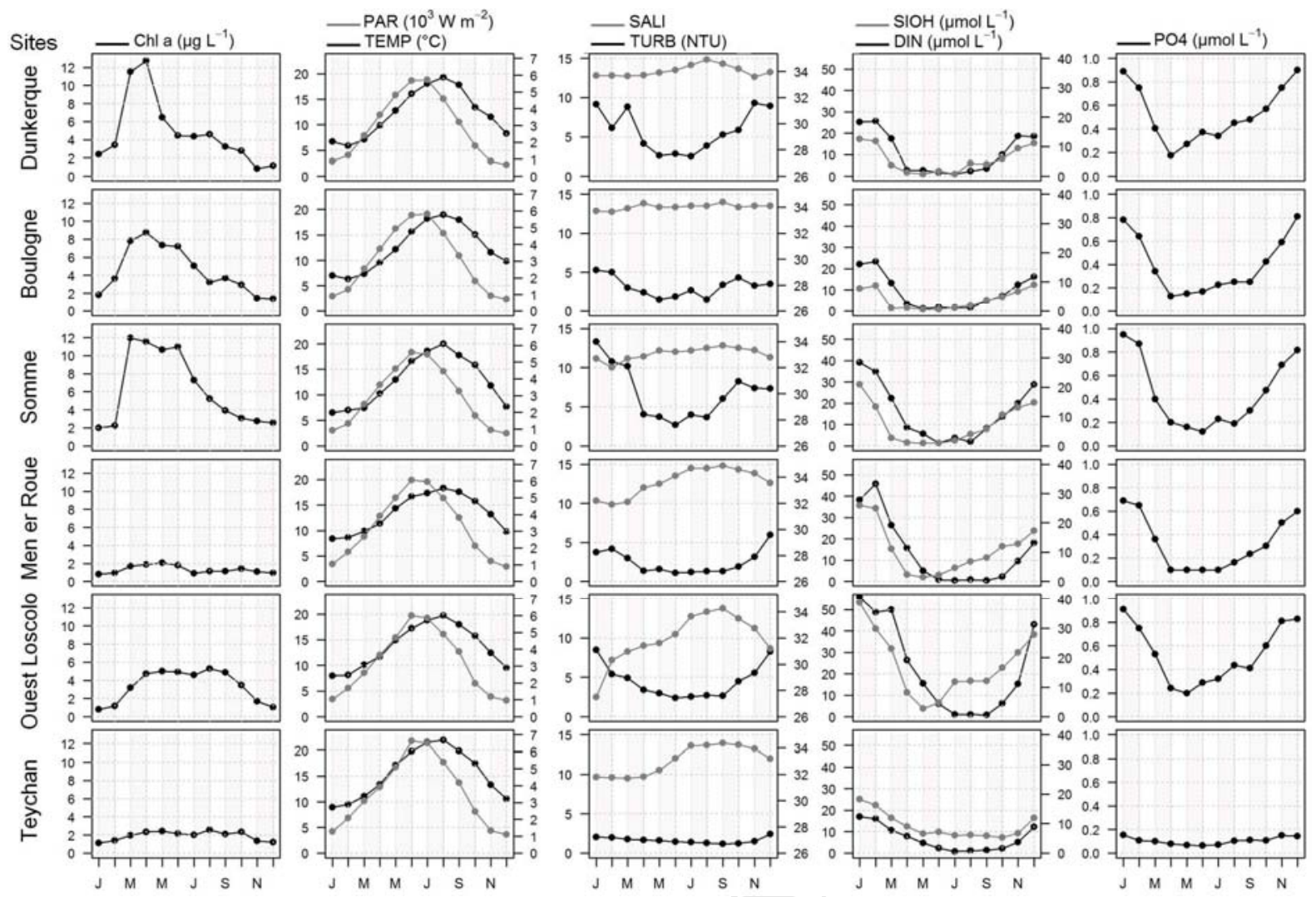


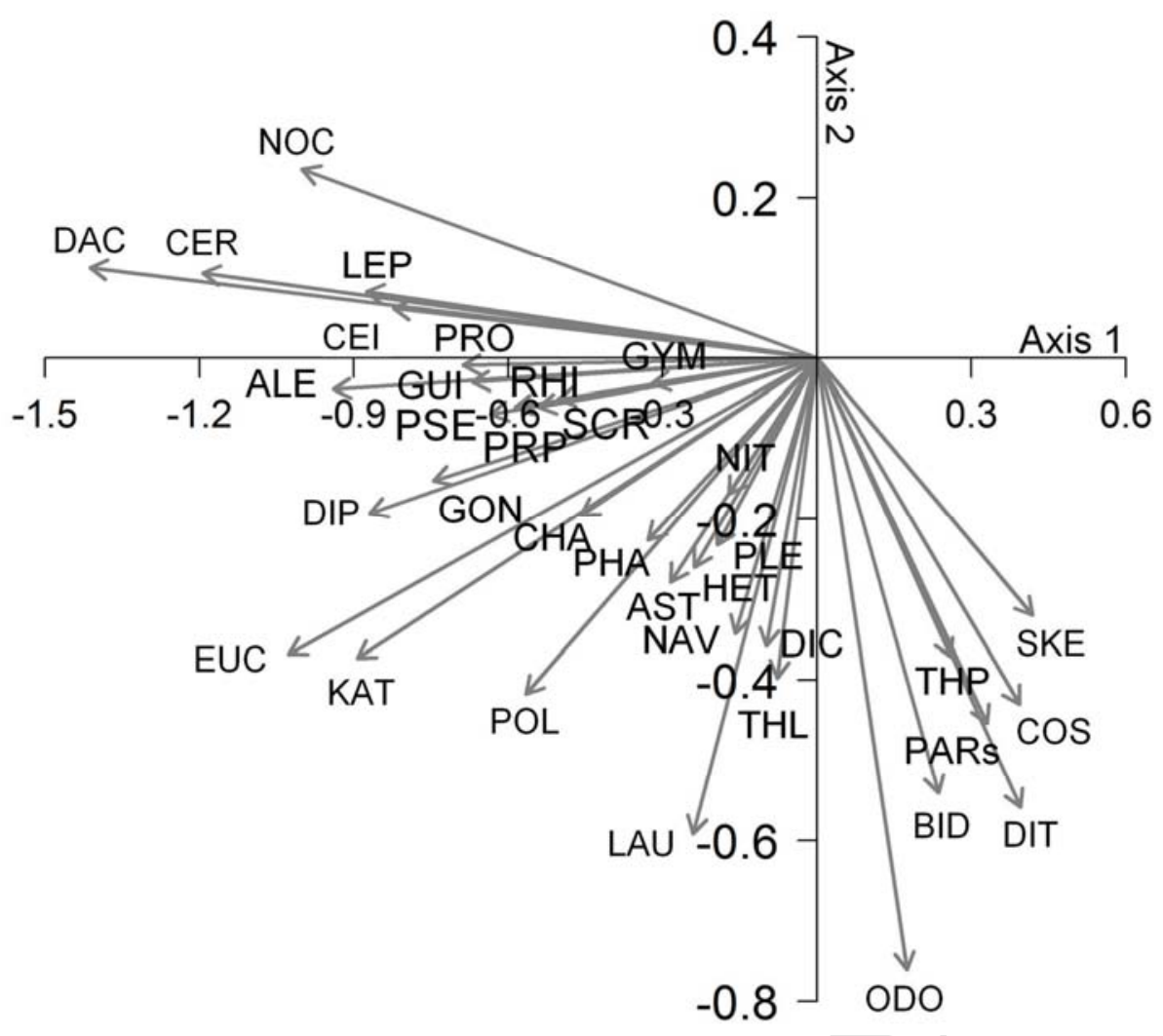


Table S1: Observed niche overlap between each phytoplankton taxonomic pair. For codes of phytoplankton units refer to Table 1 in the main text. Results of the similarity test are also highlighted. Rejection or not of the null hypothesis on both directions $(P$-value $<0.05)$ is represented by red color and acceptation by blue color. Black values represent test where the null hypothesis could not be rejected on both directions.

\begin{tabular}{|c|c|c|c|c|c|c|c|c|c|c|c|c|c|c|c|c|c|c|c|c|c|c|c|c|c|c|c|c|c|c|c|c|c|c|c|}
\hline & $A L E$ & $A S T$ & BID & CEI & CER & CHA & $\cos$ & $D A C$ & DIC & DIP & DIT & EUC & GON & GUI & GYM & I HET & KAT $I$ & $L A U \mid I$ & LEP $\mid$ & $N A V \mid N$ & \begin{tabular}{|l|l} 
NIT & \\
\end{tabular} & NOCC & ODOI & PARs & PHA & $P L E \mid P$ & POL & PRO & PRP I & PSE 1 & RHI & SCR & SKE & THP & THL \\
\hline ALE & 1 & & & & & & & & & & & & & & & & & & & & & & 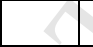 & & & & & & & & & & & & \\
\hline AST & 0.76 & & & & & & & & & & & & & & & & & & & & & & $\infty$ & & & & & & & & & & & & \\
\hline BID & 0.66 & 0.83 & & & & & & & & & & & & & & & & & & & & & 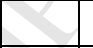 & & & & & & & & & & & & \\
\hline CEI & 0.87 & 0.82 & 0.69 & 1 & & & & & & & & & & & & & & & & & & $\infty$ & $y$ & & & & & & & & & & & & \\
\hline CER R & 0.86 & 0.72 & 0.6 & 0.86 & 1 & 1 & & & & & & & & & & & & & & & & D & & & & & & & & & & & & & \\
\hline CHA & 0.8 & 0.92 & 0.81 & 0.85 & 0.76 & 1 & & & & & & & & & & & & & & & & $\lambda$ & & & & & & & & & & & & & \\
\hline $\cos$ & 0.63 & 0.81 & 0.9 & 0.67 & 0.58 & 0.8 & 1 & & & & & & & & & & & & & & & $L$ & & & & & & & & & & & & & \\
\hline DAC & 0.84 & 0.67 & 0.54 & 0.82 & 0.89 & 0.71 & 0.52 & 1 & & & & & & & & & & & & 자․ & 2 & & & & & & & & & & & & & & \\
\hline DIC & 0.73 & 0.91 & 0.86 & 0.78 & 0.68 & 0.9 & 0.86 & 0.63 & 1 & 1 & & & & & & & & & & & & & & & & & & & & & & & & & \\
\hline DIP & 0.88 & 0.81 & 0.7 & 0.85 & 0.85 & 0.84 & 0.68 & 0.81 & 0.77 & 1 & & & & & & & & & & , & & & & & & & & & & & & & & & \\
\hline DIT & 0.61 & 0.8 & 0.9 & 0.66 & 0.55 & 0.78 & 0.9 & 0.5 & 0.84 & 0.66 & 1 & & & & & & & & 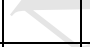 & & & & & & & & & & & & & & & & \\
\hline EUC & 0.8 & 0.75 & 0.67 & 0.76 & 0.79 & 0.77 & 0.64 & 0.78 & 0.73 & 0.87 & 0.62 & 1 & & & & & & & 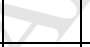 & & & & & & & & & & & & & & & & \\
\hline GON & 0.82 & 0.84 & 0.71 & 0.85 & 0.79 & 0.83 & 0.68 & 0.76 & 0.8 & 0.83 & 0.69 & 0.79 & 1 & 1 & & & & H & Z & & & & & & & & & & & & & & & & \\
\hline GUI & 0.81 & 0.85 & 0.74 & 0.87 & 0.83 & 0.89 & 0.71 & 0.76 & 0.81 & 0.86 & 0.7 & 0.78 & 0.81 & 1 & 1 & & & + & & & & & & & & & & & & & & & & & \\
\hline GYM & 0.81 & 0.88 & 0.77 & 0.86 & 0.79 & 0.92 & 0.77 & 0.73 & 0.85 & 0.84 & 0.74 & 0.77 & 0.81 & 0.93 & 1 & 1 & & y & & & & & & & & & & & & & & & & & \\
\hline HET & 0.78 & 0.85 & 0.78 & 0.8 & 0.72 & 0.87 & 0.8 & 0.68 & 0.86 & 0.78 & 0.77 & 0.75 & 0.82 & 0.79 & 0.84 & 1 & & & & & & & & & & & & & & & & & & & \\
\hline KAT & 0.79 & 0.74 & 0.66 & 0.73 & 0.76 & 0.76 & 0.64 & 0.75 & 0.72 & 0.85 & 0.62 & 0.87 & 0.73 & 0.77 & 0.76 & 0.71 & 1 & & & & & & & & & & & & & & & & & & \\
\hline LAU & 0.68 & 0.84 & 0.84 & 0.7 & 0.63 & 0.81 & 0.81 & 0.59 & 0.84 & 0.76 & 0.83 & 0.75 & 0.73 & 0.75 & 0.77 & 0.78 & 0.74 & 1 & & & & & & & & & & & & & & & & & \\
\hline LEP & 0.88 & 0.79 & 0.67 & 0.91 & 0.9 & 0.84 & 0.66 & 0.84 & 0.75 & 0.87 & 0.63 & 0.78 & 0.81 & 0.88 & 0.86 & 0.79 & 0.76 & 0.68 & 1 & & & & & & & & & & & & & & & & \\
\hline NAV & 0.77 & 0.89 & 0.86 & 0.78 & 0.71 & 0.9 & 0.85 & 0.66 & 0.89 & 0.8 & 0.82 & 0.76 & 0.77 & 0.83 & 0.87 & 0.86 & 0.76 & 0.83 & 0.79 & 1 & 1 & & & & & & & & & & & & & & \\
\hline NIT & 0.77 & 0.89 & 0.81 & 0.82 & 0.73 & 0.93 & 0.83 & 0.68 & 0.89 & 0.8 & 0.79 & 0.73 & 0.81 & 0.85 & 0.9 & 0.87 & 0.72 & 0.77 & 0.81 & 0.9 & 1 & & & & & & & & & & & & & & \\
\hline NOC & 0.82 & 0.7 & 0.59 & 0.83 & 0.87 & 0.75 & 0.58 & 0.83 & 0.67 & 0.81 & 0.55 & 0.72 & 0.74 & 0.81 & 0.78 & 0.69 & 0.72 & 0.6 & 0.87 & $0.7-0$ & 0.73 & 1 & & & & & & & & & & & & & \\
\hline ODO & 0.62 & 0.79 & 0.87 & 0.64 & 0.57 & 0.76 & 0.83 & 0.52 & 0.81 & 0.69 & 0.85 & 0.68 & 0.67 & 0.69 & 0.71 & 0.74 & 0.67 & 0.88 & 0.62 & 0.8 & 0.730 & 0.55 & 1 & & & & & & & & & & & & \\
\hline PARs & 0.66 & 0.85 & 0.91 & 0.7 & 0.6 & 0.83 & 0.94 & 0.55 & 0.89 & 0.7 & 0.91 & 0.66 & 0.72 & 0.74 & 0.79 & 0.83 & 0.66 & 0.83 & 0.68 & 0.88 & 0.850 & 0.6 & 0.85 & 1 & 1 & & & & & & & & & & \\
\hline PHA & 0.63 & 0.71 & 0.68 & 0.65 & 0.64 & 0.7 & 0.67 & 0.57 & 0.68 & 0.71 & 0.66 & 0.69 & 0.64 & 0.75 & 0.73 & 0.62 & 0.7 & 0.71 & 0.66 & 0.7 & 0.660 & 0.62 & 0.670 & 0.66 & 1 & & & & & & & & & & \\
\hline PLE & 0.79 & 0.89 & 0.82 & 0.82 & 0.74 & 0.93 & 0.82 & 0.69 & 0.88 & 0.83 & 0.79 & 0.76 & 0.8 & 0.87 & 0.92 & 0.87 & 0.75 & 0.79 & 0.82 & 0.920 & 0.940 & 0.740 & 0.750 & 0.85 & 0.69 & 1 & & & & & & & & & \\
\hline POL & 0.83 & 0.83 & 0.75 & 0.8 & 0.78 & 0.84 & 0.72 & 0.74 & 0.8 & 0.88 & 0.7 & 0.86 & 0.82 & 0.83 & 0.83 & 0.81 & 0.85 & 0.8 & 0.81 & 0.840 & 0.810 & 0.74 & 0.75 & 0.75 & 0.7 & 0.84 & 1 & 1 & & & & & & & \\
\hline PRO & 0.87 & 0.83 & 0.71 & 0.91 & 0.85 & 0.87 & 0.7 & 0.8 & 0.8 & 0.88 & 0.68 & 0.79 & 0.85 & 0.9 & 0.9 & 0.82 & 0.77 & 0.72 & 0.93 & 0.830 & 0.850 & 0.83 & 0.66 & 0.73 & 0.67 & 0.860 & 0.83 & 1 & 1 & & & & & & \\
\hline PRP & 0.85 & 0.86 & 0.75 & 0.89 & 0.82 & 0.91 & 0.74 & 0.77 & 0.83 & 0.87 & 0.72 & 0.78 & 0.84 & 0.92 & 0.94 & 0.85 & 0.76 & 0.75 & 0.9 & 0.860 & 0.90 & 0.81 & 0.69 & 0.77 & 0.7 & 0.9 & 0.84 & 0.93 & 1 & 1 & & & & & \\
\hline PSE & 0.82 & 0.87 & 0.75 & 0.87 & 0.82 & 0.9 & 0.72 & 0.75 & 0.82 & 0.86 & 0.71 & 0.79 & 0.81 & 0.96 & 0.94 & 0.8 & 0.78 & 0.76 & 0.87 & 0.84 & 0.860 & 0.8 & 0.7 & 0.75 & 0.76 & 0.88 & 0.84 & 0.9 & 0.92 & 1 & 1 & & & & \\
\hline RHI & 0.82 & 0.87 & 0.75 & 0.86 & 0.81 & 0.91 & 0.73 & 0.75 & 0.82 & 0.86 & 0.71 & 0.78 & 0.81 & 0.95 & 0.95 & 0.82 & 0.77 & 0.75 & 0.88 & 0.85 & 0.880 & 0.81 & 0.7 & 0.76 & 0.74 & 0.890 & 0.84 & 0.91 & 0.94 & 0.96 & 1 & 1 & & & \\
\hline$S C R$ & 0.86 & 0.83 & 0.72 & 0.89 & 0.82 & 0.86 & 0.71 & 0.78 & 0.81 & 0.85 & 0.7 & 0.77 & 0.87 & 0.84 & 0.86 & 0.85 & 0.74 & 0.71 & 0.89 & 0.82 & 0.870 & 0.8 & 0.65 & 0.74 & 0.63 & 0.86 & 0.81 & 0.92 & 0.9 & 0.84 & 0.86 & 1 & & & \\
\hline SKE & 0.65 & 0.82 & 0.85 & 0.69 & 0.59 & 0.81 & 0.89 & 0.54 & 0.85 & 0.67 & 0.85 & 0.62 & 0.71 & 0.72 & 0.77 & 0.82 & 0.61 & 0.76 & 0.68 & 0.84 & 0.850 & 0.6 & 0.78 & 0.91 & 0.6 & 0.82 & 0.72 & 0.72 & 0.75 & 0.73 & 0.74 & 0.74 & 1 & 1 & \\
\hline THP & 0.68 & 0.87 & 0.89 & 0.72 & 0.62 & 0.86 & 0.91 & 0.57 & 0.9 & 0.72 & 0.89 & 0.67 & 0.74 & 0.77 & 0.82 & 0.83 & 0.67 & 0.82 & 0.7 & 0.89 & 0.880 & 0.62 & 0.82 & 0.94 & 0.67 & 0.87 & 0.76 & 0.75 & 0.79 & 0.78 & 0.79 & 0.77 & 0.91 & 1 & \\
\hline THL & 0.74 & 0.9 & 0.88 & 0.77 & 0.69 & 0.91 & 0.88 & 0.63 & 0.91 & 0.78 & 0.85 & 0.74 & 0.77 & 0.82 & 0.86 & 0.85 & 0.73 & 0.84 & 0.77 & 0.92 & 0.890 & 0.68 & 0.82 & 0.9 & 0.69 & $0.91 \mid$ & $0.82 \mid$ & 0.8 & 0.84 & 0.83 & 0.84 & 0.8 & 0.84 & 0.89 & \\
\hline
\end{tabular}

